\title{
Responses to iron oxide and zinc oxide nanoparticles in echinoderm embryos and microalgae: uptake, growth, morphology, and transcriptomic analysis
}

\author{
Genevière Anne-Marie ${ }^{1,}{ }^{*}$, Derelle Evelyne ${ }^{1,2}$, Escande Marie-Line ${ }^{1}$, Grimsley Nigel ${ }^{1}$, \\ Klopp Christophe ${ }^{3}$, Ménager Christine ${ }^{4}$, Michel Aude ${ }^{4}$, Moreau Hervé ${ }^{1}$
}

${ }^{1}$ Sorbonne Université, CNRS, Biologie Intégrative des Organismes Marins, BIOM, Banyuls-sur-Mer, France

2 Univ Brest, CNRS, IRD, Ifremer, LEMAR, Plouzane, France

3 INRA, Plateforme Bioinformatique Toulouse, Midi Pyrenees UBIA, Castanet Tolosan, France

${ }^{4}$ Sorbonne Université, CNRS, PHysico-chimie des Electrolytes et Nanosystèmes InterfaciauX, PHENIX, Paris, France

* Corresponding author : Anne-Marie Genevière, email address : anne-marie.geneviere@obs-banyuls.fr

\begin{abstract}
:
We investigated the toxicity of Iron oxide and Zinc oxide engineered nanoparticles (ENPs) on Paracentrotus lividus sea urchin embryos and three species of microalgae. Morphological responses, internalization, and potential impacts of $\mathrm{Fe} 2 \mathrm{O} 3$ and $\mathrm{ZnO}$ ENPs on physiology and metabolism were assessed. Both types of ENPs affected P. lividus larval development, but ZnO ENPs had a much stronger effect. While growth of the alga Micromonas commoda was severely impaired by both ENPs, Ostreococcus tauri or Nannochloris sp. were unaffected. Transmission electron microscopy showed the internalization of ENPs in sea urchin embryonic cells while only nanoparticle interaction with external membranes was evidenced in microalgae, suggesting that marine organisms react in diverse ways to ENPs. Transcriptome-wide analysis in P. lividus and M. commoda showed that many different physiological pathways were affected, some of which were common to both species, giving insights about the mechanisms underpinning toxic responses
\end{abstract}

Keywords : Nanoparticles, toxicity, marine organisms, metal oxide, transcriptomics 


\section{Introduction}

Engineered nanoparticles (ENPs) have emerged as a new class of pollutants that may have toxic effects on ecosystems. A great variety of ENPs are now used in personal or health care products, paints, clothing, electronic devices and various other innovative goods. Consequently, ENPs are inevitably released to the environment, invading soils and waterways, through wastewater output or aerial dispersal, and ultimately reaching freshwater and marine ecosystems. According to the estimated global mass flow of ENPs from production to release (Keller and Lazareva 2014), metal oxide-ENPs (MO-ENPs) predominate in emissions to water, with titanium dioxide, zinc oxide, copper oxide, cerium dioxide and iron oxide ENPs being the most abundant discharged nanomaterials. On one hand, due to their unique properties Zinc oxide ENPs are one of the most widely used MO-ENPs. They are present in cosmetics, sunscreens and antifouling paints and are thus increasingly abundant in marine ecosystems (Ma et al. 2013, Baker et al. 2014). On the other hand, iron oxide ENPs have received increasing attention for biomedicine, biosensors (Magro et al. 2012, Marcus et al. 2016), and water treatments (Adeleye et al. 2016) leading to their consideration as emerging contaminants (Valdiglesias et al. 2016). Measurement of ENPs in natural conditions remains challenging and consequently there are only few data from the environment. Predicted environmental concentrations (PEC) have been estimated in freshwater from a few ng/L (Gottschalk et al. 2013, 2015, Lead et al. 2018) to $76 \mu \mathrm{g} / \mathrm{L}$ (Silva et al. 2011) for ZnO ENPs, in keeping with the measured concentration of $1.58 \pm 0.59 \mu \mathrm{g} / \mathrm{L}$ in effluent water samples (Majedi et al. 2012). In seawater particulate concentrations of about $30 \mu \mathrm{g} / \mathrm{L}$ for $\mathrm{Zn}$ and $6 \mu \mathrm{g} / \mathrm{L}$ for Fe have been reported (Singhal et al. 2006).

Most ecotoxicological studies on MO-ENP impacts have been focused on freshwater species (Châtel and Mouneyrac 2017, Mukherjee and Acharya 2018), but biological effects in marine species are now also well documented (Baker et al. 2014, Canesi and Corsi 2016). In aquatic 
media, the MO-ENP toxicity is highly dependent on the metal component: ZnO ENPs so far being most toxic (Mukherjee and Acharya 2018) while iron-based ENPs may be less harmful (Lewinski et al. 2008, Kadar et al. 2010). The biological activity of ENPs is also strongly related to their structure which depends on environmental conditions (Keller et al. 2010). Finally, toxicity is highly species-specific (Bondarenko et al. 2013, Exbrayat et al. 2015, Hou et al. 2018).

The fate and behaviour of MO-ENP in seawater are very different from those in freshwater. The higher alkalinity and ionic strength of the seawater as well as the presence of divalent cation and dissolved organic matter greatly influence suspended ENP structure (Blinova et al. 2010, Keller et al. 2010, Châtel and Mouneyrac 2017). Stronger aggregation or agglomeration of ENPs in seawater and a slow precipitation to the ocean floor affect ENP bioavailability. Another paradigm of ENP toxicity is the release of ions in the biological environment. Ion solubilization has been particularly well documented in the case of ZnO ENPs, where hydrated $\mathrm{Zn}^{2+}$ cations can form (Franklin et al. 2007, Xia et al. 2008, Ma et al. 2013), but the mechanism of $\mathrm{ZnO}$ ENP toxicity is still an ongoing debate (Bundschuh et al. 2018). ZnO ENP toxicity has been attributed to $\mathrm{Zn}$ ion leakage both in freshwater species (Heinlaan et al. 2008, Aruoja et al. 2009, Blinova et al. 2010, Miller et al. 2010) and in marine species (Miller et al. 2010, Wong et al. 2010, Fairbairn et al. 2011), but a recent report on marine clams has shown that ZnO ENP toxicity also depends on NP-specific features (Marisa et al. 2016). Moreover, the toxicity of ENPs on marine organisms is variable between taxonomic groups (Wong et al. 2010, Canesi and Corsi 2016, Mukherjee and Acharya 2018), but the molecular mechanisms which trigger the diversity of responses after exposure to ENPs remain largely unknown.

We compared two types of MO-ENPs known to be released in seawater, $\mathrm{ZnO}$ and $\gamma-\mathrm{Fe}_{2} \mathrm{O}_{3}$ (maghemite). To assess ENP toxicity, we chose two taxonomically distant species representing key groups in marine ecosystems, unicellular green microalgae (mamiellophycae) and 
echinoderms (sea urchin), that have previously been used as models for ecotoxicological bioassays (Brayner et al. 2011, Fairbairn et al. 2011, Gambardella et al. 2016, Torres-Duarte et al. 2017). The physicochemical properties of ENPs were characterized before evaluating the responses of organisms after exposure to ENPs. ENP internalisation was evaluated using transmission electron microscopy (TEM) and transcriptomic analyses on whole organisms were designed to make an unbiased assessment of the molecular pathways affected.

\section{Material and Methods}

\section{Preparation and characterization of metallic nanomaterials}

Magnetic Nanoparticles of maghemite $\left(\gamma-\mathrm{Fe}_{2} \mathrm{O}_{3}\right.$, mean size $\left.10 \mathrm{~nm}\right)$ were synthetized according to the Massart's process (Massart 1981). $\mathrm{FeCl}_{2}(177 \mathrm{~g}, 1.4 \mathrm{~mol})$ and $\mathrm{FeCl}_{3}(356 \mathrm{~g}, 2.2 \mathrm{~mol})$ with $\mathrm{HCl}(37 \%, 100 \mathrm{~mL}, 12 \mathrm{~mol})$ were co-precipitated by drop addition of $\mathrm{NH}_{3}(22.5 \%, 1 \mathrm{~L}, 11$ mol) in distilled water. Magnetite $\left(\mathrm{Fe}_{3} \mathrm{O}_{4}\right)$ nanoparticles formed were washed by magnetic decantation, dispersed in an acidic medium with $\mathrm{HNO}_{3}(360 \mathrm{~mL}, 52.5 \%$ in $2 \mathrm{~L}$ of distilled water) and oxidized in boiling $\mathrm{Fe}\left(\mathrm{NO}_{3}\right)_{3}(314 \mathrm{~g}, 1.3 \mathrm{~mol})$. After a magnetic decantation and a second dispersion in diluted $\mathrm{HNO}_{3}$, the magnetic nanoparticles of maghemite formed were washed three times in acetone and twice in ether. ENPs were then dispersed in water before coating with carboxymethyldextran (CMD). ZnO ENPs were synthetized as previously described (George et al. 2010), and were a generous gift of S. Pokhrel (Bremen University) (Fairbairn et al. 2011).

The ENPs dispersed in acidic media were coated with CMD (MW=15 000 g.mol ${ }^{-1},[\mathrm{COOH}]=$ 1.3 mmol.g ${ }^{-1}$, Sigma-Aldrich, St Quentin Fallavier, France) following the method of Roger et al. (Roger et al. 1999) with an addition of CMD to the initial dispersion in a ratio $[\mathrm{CMD}] /[\mathrm{Metal}]=5 \%$. They were finally ultra-filtered on MacroSep ${ }^{\circledR} 30 \mathrm{kDa}$ twice for 15 
minutes (Pall Life Sciences, VWR France, Fontenay-sous-Bois, France) and re-suspended in natural filtered $(0.2 \mu \mathrm{m})$ sea water (NFSW). The sea water was collected offshore, $5 \mathrm{~m}$ deep, and analyzed by the SOMLIT platform: $\mathrm{pH} 8.27 \pm 0.07$, salinity: $38.01 \pm 0.1 \mathrm{~g} / \mathrm{L}$, POC $55.1 \pm$ $14.3 \mu \mathrm{M}$.

The total metal concentration $(\mathrm{mol} / \mathrm{L})$ was determined by atomic absorption spectroscopy (AAS) with a Perkin-Elmer Analyst 100 apparatus after degradation of the ENPs in boiling $\mathrm{HCl}$ (35\%). The ENP-CMD suspension at $[$ Metal $]=510^{-2} \mathrm{~mol} / \mathrm{L}$ was kept at $4{ }^{\circ} \mathrm{C}$ in the dark. ENP hydrodynamic diameters (Dh) were measured in NFSW through Dynamic Light Scattering using a Zetasizer Nano ZS (Malvern Instrument) operating at the scattering angle $174^{\circ}$. The collective diffusion coefficient $\mathrm{D}$ was determined from the second-order autocorrelation function of the scattered light. ENP Dh were calculated according to the Stokes-Einstein relation, $\mathrm{Dh}=\mathrm{k}_{\mathrm{B}} \mathrm{T} / 3 \pi \eta \mathrm{D}$, where $\mathrm{k}_{\mathrm{B}}$ is the Boltzmann constant, $\mathrm{T}$ the temperature $(\mathrm{T}=298 \mathrm{~K})$ and the solvent viscosity $\left(\eta=0.89 \times 10^{-3}\right.$ Pa.s for NFSW).

\section{Handling of sea urchin gametes and embryo bioassay}

Sea urchin P. lividus fertilized eggs were obtained as described in (Hanssen et al. 2012). Briefly, adults (about $7 \mathrm{~cm}$ in diameter) were collected in the Mediterranean Sea (Banyuls-sur-mer, France) and reared until use in filtered running sea water. Spawning was induced by intracoelomic injection of 0.2 M acetylcholine. Eggs were collected in NFSW, filtered through a $100 \mu \mathrm{m}$ nylon sieve and washed three times with NFSW. For fertilization, sperm was diluted $10^{5}$ fold in a $5 \%(\mathrm{v} / \mathrm{v})$ egg suspension in NFSW. Only batches with at least $95 \%$ fertilized eggs were further used. One minute after fertilization, $500 \mu \mathrm{L}$ of eggs $(700$ eggs $/ \mathrm{mL})$ were transferred to a 24 -wells plate containing $500 \mu \mathrm{L}$ of nanomaterial or metal ion solutions at different concentrations. Final concentrations ranged from $510^{-7}$ to $510^{-5} \mathrm{~mol} / \mathrm{L}$ (from $2.810^{-}$

${ }^{5}$ to $2.810^{-3} \mathrm{~g} / \mathrm{L}[\mathrm{Fe}]$ and $3.210^{-5}$ to $3.210^{-3} \mathrm{~g} / \mathrm{L}[\mathrm{Zn}], 40 \mu \mathrm{g} / \mathrm{L} \mathrm{Fe}_{2} \mathrm{O}_{3}$ or $\mathrm{ZnO}$ ). The treatments 
were applied post fertilization (p.f.) to avoid a possible interference with the fertilization process (Tualla and Bitacura 2016). Each concentration was tested twice per plate and NFSW were used as a control. All experiments were performed at $18^{\circ} \mathrm{C}$. The number of dividing cells was recorded after 80 min (when 100\% of control cells was divided) and eggs were observed regularly with an inverted microscope (40X magnification) till the pluteus stage (48h). Each experiment was run in triplicate

\section{Culture and treatment of algae}

The three algal species O. tauri (RCC 4221), M. commoda (Noum17/RCC299) and Nannochloris sp.(sp. MBIC10596) were grown in enriched NFSW (L1 medium, Guillard and Hargraves 1993). Trace element solution and vitamins, purchased from Bigelow Laboratory (NCMA, USA) were diluted in NFSW and adjusted to $\mathrm{pH}$ 8. For culture growth and doseresponse analyzes, algae were seeded at $510^{6}$ cellules $/ \mathrm{mL}$ in $20 \mathrm{ml}$ flasks and maintained at $20^{\circ} \mathrm{C}$ under a $12 / 12$ light/dark cycle $\left(100 \mu\right.$ mole photon $\left./ \mathrm{m}^{2} \mathrm{~s}^{-1}\right)$. ENP were added $24 \mathrm{~h}$ after seeding and each condition was run in triplicate. Every 24 hours over 13 days, $300 \mu \mathrm{L}$ was sampled from each flask for cell counting. Sampled cells were preserved in 1\% glutaraldehyde, frozen in liquid nitrogen and stored at $-80^{\circ} \mathrm{C}$ until counting. Cell densities in defrosted samples were determined on a FACS Canto flow cytometer (Becton Dickinson, San Jose, CA, USA). Algae cells were counted according to their right-angle light scattering properties and their red fluorescence emission due to the chlorophyll A pigment (Trask et al. 1982). Accurate analyzed volumes and subsequent estimations of cell concentrations were calculated using Becton-Dickinson Trucount ${ }^{\mathrm{TM}}$ beads. Time course of culture growth were performed for $\mathrm{Fe}_{2} \mathrm{O}_{3}$ and $\mathrm{ZnO}$ ENPs concentrations ranging from $10^{-7}$ to $10^{-4} \mathrm{~mol} / \mathrm{L}$ (from 5.6 $10^{-6}$ to $5.610^{-3} \mathrm{~g} / \mathrm{L}[\mathrm{Fe}]$ and $6.510^{-6}$ to $6.510^{-3} \mathrm{~g} / \mathrm{L}[\mathrm{Zn}], 8 \mu \mathrm{g} / \mathrm{L}$ to $8 \mathrm{mg} / \mathrm{L} \mathrm{Fe}_{2} \mathrm{O}_{3}$ or $\mathrm{ZnO}$ ENPs). Graphs of cell densities at $48 \mathrm{~h}$ in response to increasing ENP concentrations were 
plotted using a global nonlinear regression model based on sigmoidal curve and $\mathrm{IC}_{50}$ values were determined using Graph Pad Prism version 7.00 (GraphPad, San Diego, CA, USA).

\section{Detection of ENPs by Transmission Electron Microscopy}

Cultures of the three algal species were prepared for transmission electron microscopy (TEM) as previously described (Derelle et al. 2008). TEM images of ENPs dispersed in MOLA were recorded on a JEOL 2011 microscope working at $200 \mathrm{kV}$. The sea urchin embryos were fixed according to (Crawford and Burke 2004) using Millonig's phosphate-buffered glutaraldehyde. The cells were then embedded in Epon as previously.

\section{Effect of ENPs on mRNA expression in Sea urchin, RNA-Seq transcript profiling}

Gene expression was measured using RNAseq on pools of embryos collected at midgastrulae stage. Three fertilizations were independently performed with different male and female progenitors. The resulting three batches of fertilized eggs were divided in individual cultures containing either control NFSW, $\mathrm{Fe}_{2} \mathrm{O}_{3}$ ENPs or the corresponding ions, respectively $\mathrm{Fe}^{3+}\left(\mathrm{FeCl}_{3}, 6 \mathrm{H}_{2} \mathrm{O}\right)$ or $\mathrm{Zn}^{2+}\left(\mathrm{ZnSO}_{4}, 7 \mathrm{H}_{2} \mathrm{O}\right)$. About 3000 embryos were dispatched per well of 6-well plates, each containing $4 \mathrm{~mL}$ NFSW with or without nanomaterial or metallic ions at the above indicated concentrations and maintained at $18{ }^{\circ} \mathrm{C}$ until sampling. Embryos were harvested 24 h p.f., briefly centrifuged and the resulting pellet of 2 wells (about 6000 embryos) were suspended in $200 \mu \mathrm{L}$ Thioglycerol/homogeneization solution. RNA was extracted with Maxwell 16 LEV simply RNA kit (Promega) in Maxwell 16 instrument. Purified total RNA were collected in $50 \mu \mathrm{L}$ RNase-free water and kept afterwards at $-80{ }^{\circ} \mathrm{C}$. RNA integrity (RIN) was estimated with a Bioanalyzer RNA 6000 nano and samples (RIN >9) were send to Genewiz LLC (www.genewiz.com) for preparation of libraries and sequencing. Libraries were prepared via polyA selection and sequencing, 2 x 100bp paired-ends, was performed with HiSeq2500 (V4 chemistry). 
In the Supplementary information S1, detailed protocols are reported on RNA-Seq analysis, mapping of sequenced reads and differential expression analysis. Briefly, the read quality of the RNA-Seq libraries was evaluated, a de novo transcriptome was assembled and annotated by BLAST comparison both with the genome sequences of closely related species, Strongylocentrotus purpuratus and Ciona intestinalis or with RefSeq (NCBI). Reads were realigned back to contigs and the contig expression counts were generated. Analysis of differentially expressed (DE) genes and data visualizations were performed in the R statistical environment (https://www.r-project.org/). DE genes were identified using R package edgeR (Robinson et al. 2010) with normalization for RNA composition and pairwise comparisons using the general linearized model likelihood ratio test. Contigs were accepted as significantly DE with a threshold of $1 \%$ as the false discovery rate (FDR) and when $\log C P M>0$ and $\log 2-$ fold-change $(|\mathrm{LFC}|)>1$. DE contigs were identified as enriched in Gene Ontology (GO) terms and metabolic pathways by searching against the GO and the KEGG databases (Ashburner et al. 2000, Kanehisa et al. 2006, 2008). For further comparisons, Venn diagrams were made with jvenn (http://jvenn.toulouse.inra.fr/app/example.html) (Bardou et al. 2014) to obtain the number of significantly expressed genes, which were shared among groups or unique in each experimental condition.

\section{Effect of ENPs on mRNA expression in the microalga M. commoda, RNA-Seq profiling}

Three independent cultures of M. commoda (Noum17/RCC299) were grown as described above. Flasks containing $140 \mathrm{~mL}$ were prepared from those cell cultures in early exponential phase and ENPs or the corresponding metal ions were added $24 \mathrm{~h}$ later. For RNA extraction, $100 \mathrm{~mL}$ of culture were sampled per vial $48 \mathrm{~h}$ later and the $M$. commoda cells were harvested by centrifugation at $8,000 \mathrm{~g}$ for $20 \mathrm{~min}$ at $4^{\circ} \mathrm{C}$. The pellets were then flash frozen in liquid 
nitrogen and stored at $-80^{\circ} \mathrm{C}$. Total RNA was extracted using Maxwell 16 LEV simplyRNA purification kit (Promega) in the Maxwell instrument and RNA concentration and integrity was estimated using the Bioanalyzer RNA 6000 nano (RIN $>9$ ). Selection for polyadenylated RNA, library preparation and sequencing was performed by the GeT-PlaGe GenToul platform (INRA, France). Fifteen RNA libraries were prepared using Illumina TruSeq Stranded mRNA kit. RNA libraries were sequenced on the Illumina Hi-Seq 3000 platform on 2 lines generating paired end reads of $150 \mathrm{bp}$ in length with a total of 30 million reads per sample. Bioinformatic analysis of transcriptomes is detailed in Supplementary information S2. Briefly, RNA-Seq reads were mapped on the reference $M$. commoda genome available in the JGI database (https://genome.jgi.doe.gov/pages/search-for-genes.jsf?organism=MicpuN3v2) (Worden et al. 2009) and the transcripts were quantified as TPM. Analysis of DE genes was performed as described above.

\section{Results}

\section{Physico-chemical characterization of nanomaterials}

ENPs were coated after their synthesis with $\mathrm{CMD}^{-}$Due to $\mathrm{COO}^{-}$groups, a metal-ion complex formed at the oxide $\left(\mathrm{ZnO}\right.$ or $\left.\mathrm{Fe}_{2} \mathrm{O}_{3}\right)$ surface allowing the stabilization of the particles by steric repulsion even in highly salty solutions like sea water. The mean physical diameter of coated ENPs observed in TEM was $10 \mathrm{~nm}$ (Figure 1A-B), equal to the initial ENP size, thus the coating did not change their mean diameter. To evaluate the ENP aggregation state in culture conditions, natural seawater for sea urchin embryos or seawater-based L1 medium for algal culture, the hydrodynamic diameter $\mathrm{D}_{\mathrm{h}}$, i.e. the physical diameter with its solvation layer, was measured. Immediately after their dispersion in NFSW at $20^{\circ} \mathrm{C}, \mathrm{D}_{\mathrm{h}}$ for $\mathrm{Fe}_{2} \mathrm{O}_{3}$ ENPs was 70 $\mathrm{nm}$, instead of $33 \mathrm{~nm}$ in distilled water (Bachelet-Violette et al. 2014), and $90 \mathrm{~nm}$ for $\mathrm{ZnO}$ ENPs. $\mathrm{Fe}_{2} \mathrm{O}_{3}$ ENPs displayed a slight negative charge with a zeta potential of $-7 \mathrm{mV} . \mathrm{D}_{\mathrm{h}}$ 
increased afterwards very rapidly with time until a threshold corresponding to the sedimentation point (6h, $1448 \mathrm{~nm}$ ) (Figure 1C). Without CMD, ENP precipitation was immediate (data not shown), thus the coating helped to maintain the ENPs in suspension for longer during the toxicity experiments. When measured just after dispersion in NFSW-based L1 medium, $\mathrm{D}_{\mathrm{h}}$ for $\mathrm{Fe}_{2} \mathrm{O}_{3}$ ENPs was $39.2 \mathrm{~nm}$ with a zeta potential of $-6 \mathrm{mV}$. A further characterization by TEM of $\mathrm{Fe}_{2} \mathrm{O}_{3}$ ENP behaviour over $48 \mathrm{~h}$ in $\mathrm{L} 1$ medium showed the presence of large aggregates of ENPs but no morphological change of nanoparticles indicating that they are not degraded (Figure 1D-F). Stock suspensions of coated ENPs were further diluted in NFSW or L1 medium just before use in the bioassays. Our rationale was to find experimental conditions that lead to assessable alterations of the selected physiological endpoints in bioassays to permit insights to be gained about the mechanisms induced by exposure to ENPs. Finally, the range of concentrations retained for bioassays were $10^{-7}$ to $10^{-4} \mathrm{~mol} / \mathrm{L}$ for $[\mathrm{Fe}]$ or $[\mathrm{Zn}](8 \mu \mathrm{g} / \mathrm{L}$ to $8 \mathrm{mg} / \mathrm{L}$ $\mathrm{Fe}_{2} \mathrm{O}_{3} \mathrm{ENP}$ and $8.1 \mu \mathrm{g} / \mathrm{L}$ to $8.1 \mathrm{mg} / \mathrm{L} \mathrm{ZnO} \mathrm{ENP),} \mathrm{which} \mathrm{include} \mathrm{the} \mathrm{reported} \mathrm{values} \mathrm{of} \mathrm{PEC.}$

\section{Sea urchin embryotoxicity}

Sea urchin P. lividus embryos were exposed to $\mathrm{ZnO}$ or $\mathrm{Fe}_{2} \mathrm{O}_{3}$ ENPs, and their corresponding metal ions, during a 48h developmental time course (Figure 2). Malformations in embryos were classified according to Carballeira et al. (Carballeira et al. 2012), compared to embryos developing in control conditions (NFSW). Abnormalities extended from incorrect location of skeletal rods to developmental blocks, depending on the treatment. Zn-containing chemicals, either ENPs or soluble $\mathrm{ZnSO}_{4}$, were toxic to developing embryos, with a higher toxicity of the ionic form $\mathrm{Zn}^{2+}$ (Figure 2F). Larvae with cross or non-joining tips of skeletal rods or deformed arms were observed at lower concentrations, while gastrulation was altered with severe impairment of spicules elongation at concentrations of 10-5 mol/L [ $\mathrm{Zn}]$ of $\mathrm{ZnO}$ ENPs $\left(6,510^{-}\right.$ ${ }^{4} \mathrm{~g} / \mathrm{L}$ ) and above (Figure 2D). In contrast, $\mathrm{Fe}_{2} \mathrm{O}_{3}$ ENPs did not induce major developmental 
delay or severe abnormal morphologies (Figure 2B). However, a significant heterogeneity in the size of the treated larvae at the pluteus stage was observed (Figure $\mathrm{S} 1$ ). $\mathrm{Fe}^{3+}$ did not alter embryo development (Figure 2C).

We then investigated by TEM whether the limited toxic effect of $\mathrm{Fe}_{2} \mathrm{O}_{3}$ ENPs could be attributed to a lack of penetration in embryos. Figure 3 shows the internalization of ENPs which accumulate in cytoplasmic vesicles of ectodermal cells or in vesicles bordering the outer cell membrane. Elemental analysis confirmed the particle identity with sizes of about $10 \mathrm{~nm}$ in diameter (Figure 3D). Fertilization membrane removal before ENP addition did not change ENPs localization even if a slightly higher density of ENPs-containing vesicles was observed (data not shown).

\section{Effects of ENPs on gene expression in sea urchin embryos}

Sea urchin fertilized eggs were exposed for $24 \mathrm{~h}$ to $\mathrm{Fe}_{2} \mathrm{O}_{3}$ and $\mathrm{ZnO}$ ENPs concentrations which produced morphological alterations from gastrula onward $\left(5.010^{-5} \mathrm{~mol} / \mathrm{L}[\mathrm{Fe}], 10^{-5} \mathrm{~mol} / \mathrm{L}[\mathrm{Zn}]\right)$ or to an equivalent ionic concentration of soluble metal. Using Illumina RNA-Seq, a mean of 8,5 $10^{7}$ read pairs were obtained from control and treated samples (GEO-GSE1404). The number of sequences in cDNA libraries ranged from 25 to 34 million (100bp) read pairs. The de novo transcriptome was assembled leading to 63389 contigs. Quantitative data on the comparative transcriptome analysis are summarized in Supplementary data files S1 (upregulated contigs) and S2 (down-regulated contigs). The number of DE genes in response to metal exposure are reported in Table 1 and visualized as Venn diagrams in Figure 4.

\section{Table 1 position}

Only few predicted contigs were DE after $\mathrm{Fe}_{2} \mathrm{O}_{3}$ ENPs or $\mathrm{FeCl}_{3}$ exposure with the applied criteria. This result was concordant with the weak morphological effect observed in presence 
of iron. Only one contig (Sina_LOC587958.3.3), predicted as the zinc transporter ZIP12, was up-regulated in response to $\mathrm{Fe}_{2} \mathrm{O}_{3}$ ENPs. This gene was not altered by $\mathrm{FeCl}_{3}$ but highly downregulated $(|\mathrm{LFC}|>3)$ in response to $\mathrm{Zn}$, either as ENPs or ion. The remaining three $\mathrm{Fe}_{2} \mathrm{O}_{3} \mathrm{ENP}$ DE contigs were down-regulated, one of them (Sina_LOC577189.1.2, an endoglucanase) being repressed regardless of the treatment. In contrast, a much larger set of contigs were DE when embryos were challenged with $\mathrm{ZnO}$ ENPs and to an even greater amount in response to $\mathrm{ZnSO}_{4}$ treatment.

To highlight the more important biological processes (BP) or molecular functions (MF) participating in the ENP response, a GO analysis was performed (Figure S2). This analysis revealed that the processes most affected both among the up-regulated and the down-regulated contigs were related to "transcription regulation". The fraction of genes involved in "metalloendopeptidase activity" was also enriched among the up-regulated contigs. Despite having a lower $\mathrm{p}$-value, these $\mathrm{GO}$ terms were also enriched upon $\mathrm{ZnSO}_{4}$ treatment.

Among the 196 DE contigs highly up-regulated (LFC $>3$ ) after ZnO ENP exposure, 23 encoded proteins of the metallothionein (MT) family (w/o an assigned GO term), all of them being more severely induced upon $\mathrm{ZnSO}_{4}$ exposure (Figure S3). Seven were also up-regulated, though more weakly, in the presence of $\mathrm{FeCl}_{3}$ while none of them were stimulated by $\mathrm{Fe}_{2} \mathrm{O}_{3}$ ENPs. $\mathrm{A}$ notable effect was also observed for three contigs encoding metalloendopeptidases, MMP16 precursor, $B P 10$ and a type IV collagenase, which are highly induced in response to zinc, either as ENP or ionic. Nine other Zn-dependent contigs encoding metalloendopeptidases were also induced, less severely, in response to both forms of zinc metal.

Among the highly up-regulated contigs responding to $\mathrm{ZnO}$ ENPs, 17 were related to the enriched BP-transcription regulation GO terms. Several of these genes belong to the signalling pathways that specify cell fate along the sea urchin developmental axes such as FoxQ2, Admp1 and 2, Unc4 or Lefty (Figure S4). Other components of the gene regulatory networks (GRNs) 
which control development patterning, although not classified under this GO group, were highly down-regulated, including genes such as ankAT-1, dkk3 or sfrp5. Moreover, in agreement with the complete inhibition of spicule growth when embryos were challenged with $\mathrm{ZnO}$ ENPs, the expression of the spicule matrix gene SM30 was found to be repressed in response to $\mathrm{ZnO}$ ENPs and $\mathrm{ZnSO}_{4}$. This inhibition was confirmed by qPCR (data not shown). The BP-GO "transmembrane transport" type of functions were also enriched. These included predicted Zn transporters of the ZIP family, ZIP 10 and 12, ZIP12 being more highly downregulated by $\mathrm{ZnO}$ ENPs and $\mathrm{Zn}^{2+}$ while up-regulated by $\mathrm{Fe}_{2} \mathrm{O}_{3}$ ENPs, as mentioned above and not affected by $\mathrm{Fe}^{3+}$. In addition, MF-GO terms related to "Acetyl-CoA or biotin carboxylase activities" were also enriched among the highly down-regulated contigs. A KEGG analysis of these contigs showed that the encoded ACAC.1.3, 2.3 and 3.3 proteins belong to the AMPK signalling pathway which affects fatty acid biosynthesis. The enriched cholinesterase activity GO term includes the Cholinesterase 1 and 2 encoding contigs, the second one being highly down-regulated. Many of the contigs that were highly regulated in response to ZnO ENPs were also highly affected after exposure to $\mathrm{ZnSO}_{4}$, however our analysis also revealed DE contigs specifically responding to $\mathrm{ZnO}$ ENPs but not to $\mathrm{ZnSO}_{4}$ (Figure 4). Twenty-nine contigs in the latter group were highly stimulated, including a multidrug and toxin extrusion protein (Sina_LOC100891823) and a tubulin alpha-1 chain (TBA1.1.12), while 53 genes were highly repressed, most of them encoding uncharacterized proteins.

\section{Culture growth responses of microalgae}

Iron and zinc ENP toxicity was tested on three strains of picophytoplankton, O. tauri and $M$. commoda (both of the Mamiellophyceae class) and Nannochloris sp (class Trebouxiophyceae). Growth of $O$. tauri and Nannochloris were unaffected by the presence of ENPs in the culture medium (data not shown). In contrast, when M. commoda cultures were exposed to iron or zinc 
ENPs, their exponential growth stopped rapidly and in a dose-dependent way (Figure 5). IC50 measurement at $48 \mathrm{~h}$ showed that this algal strain is more sensitive to $\mathrm{ZnO}$ ENPs (IC50 $=4.35$ $10^{-6} \mathrm{~mol} / \mathrm{L}$, with a $95 \%$ confidence interval $(\mathrm{CI}): 3.55$ to $5.3710^{-6} \mathrm{~mol} / \mathrm{L}$ ) than $\mathrm{Fe}_{2} \mathrm{O}_{3}$ ENPs $\left(\mathrm{IC} 50=3.1910^{-5} \mathrm{~mol} / \mathrm{L}\right.$ with $95 \% \mathrm{CI}: 2.72$ to $\left.3.9310^{-5} \mathrm{~mol} / \mathrm{L}\right)$.

To investigate if $\mathrm{Fe}_{2} \mathrm{O}_{3}$ ENPs penetrate the algal cells as they do in sea urchin embryonic cells, ENP-treated $O$. tauri and M. commoda algae were examined by TEM $48 \mathrm{~h}$ after addition of ENPs. We observed neither internalization nor morphological perturbation of $O$. tauri cells, in agreement with the lack of cell growth inhibition. In contrast, $M$. commoda cell morphology was severely perturbed and we rarely observed intact flagella (Figure 6). ENPs were never visualized inside the cells without simultaneous membrane degradation and cell lysis. $\mathrm{Fe}_{2} \mathrm{O}_{3}$ ENP aggregates were often seen in close contact with the outer membrane (Figure 6 C,D) of cells with damaged envelope. In addition, depending on the species of alga the abundance of $\mathrm{Fe}_{2} \mathrm{O}_{3}$ ENP aggregates in the medium varied, with larger and more abundant aggregates for $O$. tauri and Nannochloris than for M. commoda (Figure S5).

\section{M. commoda transcriptomic response to ENP exposure}

We used RNA-Seq to compare gene expression patterns of the ENP-sensitive algae $M$. commoda cultured with or without metal oxide ENPs. Concentrations of ENPs were chosen from the growth profile described above to produce 60 to $80 \%$ growth inhibition of cultured cells: $310^{-5} \mathrm{~mol} / \mathrm{L}$ [Fe] for $\mathrm{Fe}_{2} \mathrm{O}_{3}$ ENPs and $10^{-5} \mathrm{~mol} / \mathrm{L}$ [Zn] for ZnO ENPs. Parallel cultures were treated with an equivalent ionic concentration of $\mathrm{Fe}^{3+}$ or $\mathrm{Zn}^{2+}$. M. commoda cells were collected $48 \mathrm{~h}$ after addition of the chemical compounds, when control cultures were still growing exponentially. For each sample, a fraction of the cell culture was harvested and total RNA was extracted, the growth rate of remaining cells being surveyed till day 10 (Figure S6). Only the ENP form of the metal oxides altered the growth rate of the M. commoda cultures. 
RNAs were processed for preparation of libraries and further Illumina sequencing (NCBIGEO-GSE140694). The RNA-Seq reads for each sample, mapped back to the M. commoda genome sequence, were used to calculate the expression level of unigenes and analyse the DE genes (Supplementary data, files S3 and S4). The numbers of DE genes for each comparison are summarized in Table 2 and visualized as Venn diagrams in Figure 7.

\section{Table 2 position}

The impact of $\mathrm{FeCl}_{3}$ was very weak (only $0,3 \%$ of $\mathrm{DE}$ genes with $|\mathrm{LFC}|>3$ ) and similarly, very few genes were highly repressed $(0,7 \%)$ in response to $\mathrm{ZnSO}_{4}$, but a higher proportion of them was induced. The slightly more pronounced response to $\mathrm{Zn}^{2+}$ compared to $\mathrm{Fe}^{3+}$, with a higher proportion of up-regulated than down-regulated genes, matched with the observed small delay in the growth profile at $48 \mathrm{~h}$ post $\mathrm{Zn}^{2+}$ addition.

Of the $918 \mathrm{DE}$ genes specific to ENPs (common to $\mathrm{Fe}_{2} \mathrm{O}_{3}$ and $\mathrm{ZnO}$, not responding to ions), 7 $(0,2 \%)$ were highly induced, with 3 having a predicted annotation: $S f S A$, a transcription factor involved in maltose metabolism, MFS1, a transporter of the Major Facilitator Superfamily and RCC1 a Regulator of Chromosome Condensation (Figure S7). Only one gene, MDH5, orthologous of the C. reinhardtii NADP-dependent malate dehydrogenase (EC 1.1.1.37) was highly repressed. In addition, the $h s p 90$ genes encoding stress chaperone proteins were either specifically altered or more intensively altered by ENPs than their corresponding ions while ENPs specifically induced $h s p 20$ expression. Two essential cell cycle genes were also preferentially repressed in response to ENPs, albeit to a lesser extent (lower LFC), CDKD, the CDK activating kinase, and $A P C 3$ a subunit of the Anaphase Promoting Complex (Figure S7). Among the genes up-regulated in response to ENP exposure, the GO terms linked to the BPmicrotubule-based movement predominated (Figure S8). Several transcripts in this GO group were highly induced in response to both ENPs as well as $\mathrm{Zn}^{2+}$ ions, but not induced or to a lower extent by $\mathrm{Fe}^{3+}$ ions (Figure S7), for example the gene encoding dynein heavy chain, 
DHC6, involved in the movement of flagella (Mitchell 2007), and the CDHC1B gene or PKD2, a member of the TRP family of $\mathrm{Ca}^{2+}$-permeable nonselective cation channels (Tsiokas 2009) which participates in intra-flagellar transport and calcium signaling in Chlamydomonas (Huang et al. 2007).

Among the down-regulated genes, "translation" was the main biological process altered by ENPs and $\mathrm{Zn}^{2+}$, associated to the over-representation of genes linked to the MF "structural constituent of ribosome" and "translation initiation" (Figure S8). Several genes relevant to these GO terms were highly down-regulated ( $|\mathrm{LFC}|>3)$ upon ENPs exposure, i.e. the ribosomal protein L1, the Lysyl-tRNA synthetase and the eIF4-gamma/eIF5/eIF2-epsilon described gene, but none gene of these groups was notably repressed by the corresponding ions. In addition, several genes related to nitrogen transport, either ammonium transporters (AMT) or nitrate transporters (NRT), were strongly down-regulated by both ENPs (Figure S7) but only changed weakly by the metal ions.

\section{Discussion}

We investigated the toxicity of two types of MO-ENPs $\left(\mathrm{Fe}_{2} \mathrm{O}_{3}\right.$ and $\left.\mathrm{ZnO}\right)$ on two different marine taxonomic groups, echinoderms and micro-algae. To our knowledge, this is the first report using a global gene expression approach to survey the molecular mechanisms affected by exposure to MO-ENPs in these marine organisms, and it provides new insight about $\mathrm{MO}$ ENP toxicity.

Upon dispersion in NFSW or algal culture media, ENPs rapidly formed aggregates as evidenced by Dh increase (Figure 1C). Moreover, visualization by TEM showed that this tendency to form aggregates varied in L1 algal media according to the species in culture (Figure S5). This shows that not only the SW ionic strength and organic matter content affect the ENP aggregation kinetics and settling rates (reviewed in Lead et al. 2018) but also that the interactions with organisms may influence ENP structure and in turn alter the ENP bioavailability and toxicity. 
Mode of interaction and biological response in sea urchin embryos

TEM analysis showed that $\mathrm{Fe}_{2} \mathrm{O}_{3}$ ENPs penetrated the fertilization envelope and the plasma membrane of ectodermal cells of the sea urchin embryos, accumulating in cytoplasmic vesicles (Figure 3). This translocation through the plasma membrane probably occurs by endocytosis due to the high level of this kind of trafficking during early sea urchin development (CovianNares et al. 2008, Wu et al. 2015). Internalization of silver as well as copper or zinc oxide ENPs was already observed in different species of sea urchin embryos (Piticharoenphun et al. 2012, Wu et al. 2015, Torres-Duarte et al. 2016). In mammalian cells, CMD-coated maghemite ENPs were shown to be stored in lysosomes (Levy et al. 2011, Satori et al. 2011) where they are expected to be degraded under acidic conditions. Such ENP sequestration, in endosomes or lysosomes, given the harmelessness of the iron ionic form $\left(\mathrm{Fe}^{3+}\right)$, probably explains the low toxic effect observed in sea urchin embryos. Conversely, both $\mathrm{ZnO}$ ENPs and $\mathrm{ZnSO}_{4}$ were highly toxic for these embryos (Figure 2). (Fairbairn et al. 2011) attributed the toxicity of noncoated $\mathrm{ZnO}$ ENPs on sea urchin embryos mainly to soluble $\mathrm{Zn}^{2+}$. However, using CMD-coated $\mathrm{ZnO}$ ENPs, we found that only $6 \%$ of the $\mathrm{Zn}$ content was solubilized in 24 hours (data not shown). Nevertheless, strong morphological alterations were observed in embryos. This suggests that toxicity of ZnO ENPs was only partly related to their solubility, the action of other ENPs physicochemical characteristics being also important for the resulting toxic effect, as already reported in sea urchin and other marine organisms (Wong et al. 2010, Manzo et al. 2013, Zhao et al. 2013, Yung et al. 2015, Kim et al. 2017, Oliviero et al. 2017). The transcriptomic analysis identified overlap in the responses to ionic and NP forms of zinc in $P$. lividus with often stronger perturbation of the gene expression for the ionic form (higher LFC). However, marked differences were also found in the elicited BP indicating a distinct effect of the particulate form compared to the ionic one. Nevertheless, no one gene was specifically 
altered by both iron-and zinc-based ENPs in sea urchin, probably because the surface properties of ENPs are unique to each MO.

The global gene expression analysis in response to ZnO ENP exposure revealed changes in various cell mechanisms including a repression of metal uptake, a strong induction of metal binding proteins, an alteration of detoxification processes and a severe repression of genes which regulate developmental patterning of sea urchin embryos.

To cope with external zinc excess, genes encoding proteins of the ZIP family, which facilitate zinc/iron uptake to the cytosol and regulate gene homeostasis (Baltaci and Yuce 2018), were repressed. In contrast, the expression of the heavy metal binding MT were massively induced. MT induction was a common response upon exposure to the ionic form of zinc, cadmium or manganese in sea urchin embryos (Roccheri et al. 2004, Migliaccio et al. 2014, Ragusa et al. 2017) but also to ZnO ENP in nematode (Ma et al. 2009, Polak et al. 2014). In addition to be the main metal-responsive genes in many systems, MT are also sensitive to oxidative stressors or irradiation (Russo et al. 2014), since they participate in scavenging of the reactive oxygen species (ROS). Induction of ROS and the resulting oxidative stress is the most commonly reported mechanism of nanotoxicity (Al-Subiai et al. 2012, Rocha et al. 2015, Marisa et al. 2016). In sea urchin embryos, NADPH-oxidase (Nox) induction evokes the production of ROS, but superoxide dismutase (SOD) or catalase (CAT) stimulation were not observed, suggesting that ROS scavenging could be ensured mainly by the MT redox cycle rather than the glutathione redox complex. On the other hand, the detoxification processes were disrupted: a predicted Cytochrome P450 (Phase I detoxification process) was repressed and gluthatione S-transferase (GST) encoding genes (Phase II) were either stimulated (GST- $\Omega$ and GST- $\theta$ ) or inhibited (GST- $\alpha$ ). In addition, the genes encoding the Multidrug Resistance-associated Proteins (MRP) were repressed. These ABC-transporter proteins, which normally protect embryos against 
xenobiotics, were already shown to be inhibited by $\mathrm{Zn}$ and $\mathrm{Cu}$ ENPs and to be responsible for a chemosensitizer effect of ENPs in sea urchin embryos (Wu et al. 2015).

Despite the stimulation of defence mechanisms, strong alterations of embryos development were induced by $\mathrm{ZnO}$ ENPs treatment. The morphological alterations were visible from gastrula onward. The lack of alteration of cleavage stages demonstrated that cell division itself was not affected and accordingly the expression of cell cycle-related genes was not modified. In contrast, $\mathrm{ZnO}$ ENPs mainly perturbed the "DNA-dependent transcriptional regulatory processes" (Figure S2), which are only required in sea-urchin for post-blastula development. Similarly, microarray data showed that Ag nanotube exposure led to down-regulation of numerous genes related to DNA-dependent transcriptional regulation in zebrafish embryos (Park and Yeo 2015). Most of these repressed genes, as well as those related to the overrepresented "growth processes", are part of the signalling pathways that specify cell fate along the sea urchin developmental axes: foxQ2, AnkAT-1, sfrp5 and dkk3, admp1 and 2, Lefty,etc. (Figure S5). Their down-regulation is well correlated with the observed failure in gut and skeleton formation (Fig. 2D) as detailed in Supplementary information S3. The disruption of genes involved in the TGF- $\beta$ signalling pathway, which regulate skeletal morphogenesis (Sun and Ettensohn 2017), may explain the consecutive down-regulation of SM30, a marker of skeletal development which was already shown to be repressed in response to Cd (Marrone et al. 2012, Migliaccio et al. 2014). Trans-membrane transport processes and in particular $\mathrm{Ca}^{2+}$ transport are also over-represented in down-regulated genes. This alteration may participate, in addition to SM30 repression, to a biocalcification defect leading to skeleton disruption. In addition, disruption of calcium homeostasis during early developmental stages, as well as generation of ROS, are known to disturb the establishment of embryo axes (Akasaka et al. 1997, Coffman and Davidson 2001).

Mode of interaction and biological response in microalgae 
Growth of M. commoda was inhibited by both ENP types whereas O. tauri and Nannochloris were unaffected. In the corresponding microalgal culture media, the ENP aggregation propensity was negatively correlated with the observed toxicity. The extracellular polymeric substances (EPS) secreted by algae are known to enhance the aggregation of ENPs, limiting their interaction with the microalgae surface and the ENP toxic abilities (Quigg et al. 2013, Chiu et al. 2017, Morelli et al. 2018, Chen et al. 2019). In the M. commoda transcriptomic analysis, we noted that the $A M Y A 1 \propto$-amylase encoding gene which belongs to the starch and sucrose metabolic pathway (map 00500, Figure S9) was strongly induced by ENPs (LFC>3), supporting the hypothesis of a stimulation of the carbohydrate metabolism also in this species. While this stimulation was not sufficient to shape a protective bio-barrier in M. commoda, a higher EPS secretion in O. tauri and Nannochloris could explain a decreased bioavailability and a reduced toxicity in these two species.

In $M$. commoda, ENPs, but not the metal ionic forms, strongly inhibited growth. The analysis of DE genes showed that two zinc/iron permeases of the ZIP family were specifically repressed by ENP, suggesting a response to cope with metal ion excess. ENPs were never observed by TEM inside cells of this alga, which does not possess cell wall. In contrast, ENP aggregates were found in close contact with the external membrane of lysing cells (Figure 6) suggesting that damage to the cell membrane is a critical step of cytotoxicity.

The gene expression analysis showed that oxidative stress mechanisms were activated upon exposure to both kinds of ENPs. Genes responsive to ROS production, such as $\mathrm{Cu}-\mathrm{Zn}$ SOD3 superoxide dismutase, ODA-LC 3 or 5 thioredoxin family members and CCP 1 peroxidase were induced. A large number of studies indicate that oxidative stress is the dominant toxicity mechanism of ENPs on algae (von Moos and Slaveykova 2014) and that ROS exceeding the scavenging capacity of antioxidative enzymes would directly damage the cell membrane (Chen et al. 2019). In contrast to sea urchin, scavenging proteins of the MT family were poorly 
induced in $M$. commoda (wlab. 246805.1) or even repressed (wlab.240127.1). In contrast, MDH5, a chloroplast-localized protein which contributes to avoiding radical formation, was found highly and specifically induced by ENP exposure (Scheibe 2004). Moreover, we noted an over-representation of the up-regulated genes related to photosynthesis light harvesting (LH) processes and in particular the ENP-specific up-regulation of LHCSR2 and several members of the $C B R / E L I P$ family. This family of light-harvesting-related proteins is not only induced in response to photo-oxidative stress (Montané and Kloppstech 2000, Cuvelier et al. 2017) but are also responsive to other types of stress in plants, including cold stress (Montané et al. 1999). Their stimulation after ENP exposure is, as far as we know, the first reported response to a physico-chemical stress in algae. Another sign of ENP-induced stress in this algae is the specific induction of isoforms of $h s p 20$ by both ENPs (Supplementary data file S3). In addition, expression of genes involved in the detoxifying mechanisms such as GST2, CYP97C of the cytochrome P450 family and two members of the ATP-binding cassette efflux transporters (ABC) were specifically repressed by ENPs.

The biological processes related to microtubule-based movement are preferentially represented among the up-regulated transcripts in response to ENPs (Figure S8). Among the up-regulated transcripts relevant to this pathway are the dynein DHC6 and the cation channel PKD2, both involved in the movement of the flagellum (Huang et al. 2007). These changes might be the cause of the flagellar damage observed in the cultures. A loss of flagella was also observed in the microalga D. viridis after exposure to cerium oxide ENP (Klimova et al. 2019). Conversely, the most abundant groups of down-regulated transcripts consisted of genes involved in translation, suggesting a decrease in the protein content or the production of misfolded proteins. A similar severe alteration of translation was observed in Arabidopsis thaliana, in bacteria treated with ZnO ENP (Landa et al. 2012, Su et al. 2015), in the fresh water phytoplankton cyanobacterium Microcystis aeruginosa exposed to silver ENPs (Qian et al. 2016) or in 
copepods challenged with nickel ENPs (Zhou et al. 2018). Finally, essential cell cycle genes (CDKD, APC3), were specifically repressed by ENPs, probably a critical step in $M$. commoda growth inhibition.

\section{Conclusion}

This analysis confirmed that marine organisms respond in a highly variable way to ENPs. TEM revealed that ENPs penetrated sea urchin embryos, where they accumulate in cell vesicles, presumably endosomes or lysosomes. In contrast, ENPs were not internalized by the tested microalgal cells, but interacted closely with the external cell surface inducing pronounced damage to the plasma membrane and cell lysis. The induced biological responses were also distinct: while sea urchin embryos were sensitive (to different extents) to both ENPs, microalgae responded in a highly species-dependent manner; growth of $M$. commoda was inhibited by both ENP types whereas O. tauri and Nannochloris were unaffected. Notably, in M. commoda only the ENP forms of Fe and $\mathrm{Zn}$ were toxic, while in sea urchin the ionic form of zinc produced morphological alterations at lower [Zn] than the ENP form. However, in both echinoderm and algae, zinc-based ENPs had a higher toxicity than iron ENPs, though growth of $M$. commoda was severely inhibited by $\mathrm{Fe}_{2} \mathrm{O}_{3}$ ENPs.

The transcriptomic analysis confirms that the outcomes of MO ENP exposure differ according to the metal oxide and the species. However, in both kinds of reactive organisms, responses linked to the nanoparticular structure were evidenced. Indeed, MO ENPs and their corresponding ions elicited different patterns of gene expression in both model organisms. ENPs induce alterations of some common molecular mechanisms in both organisms, such as in the transmembrane transport, which ensures metal homeostasis, the detoxifying mechanisms, and the $\mathrm{Ca}^{2+}$ transport or calcium signalling pathways. The response to oxidative stress is also observed in both species but the respective involvement of detoxifying and redox responses 
differ according to the species. Moreover, potential biomarkers of ENP exposure have been identified and should be confirmed by further experiments.

\section{Acknowledgements,}

The authors would like to dedicate this publication to Dr. Hervé Moreau who died unexpectedly during the revision of this article.

The authors thank Dr. Pascal Giraud and the ORDECO organization (https://www.ordeco.org/) for fruitful discussions and assistance during the project, Christophe Salmeron (SU/CNRS BioPIC Imaging and OOB Cytometry platform) for cytometry analysis, Elodie Desgranges (OOB-UMR7232) for technical assistance in microalgae culture, and the microscopy platform of the Institut des Matériaux de Paris Centre (IMPC) - Fédération de Recherche 2482.

\section{Funding}

The authors thank the CNRS (Missions pour les initiatives transverses et interdisciplinaires) and EMBRC.France for financial support.

\section{Supplementary information}

Supplementary information to this article is available online

\section{Declaration of interest statement}

The authors declare that there is no conflict of interest regarding the publication of this article. 


\section{References}

Adeleye, A.S., Conway, J.R., Garner, K., Huang, Y., Su, Y., and Keller, A.A., 2016.

Engineered nanomaterials for water treatment and remediation: Costs, benefits, and applicability. Chemical Engineering Journal, 286, 640-662.

Akasaka, K., Uemoto, H., Wilt, F., Mitsunaga-Nakatsubo, K., and Shimada, H., 1997. Oral— aboral ectoderm differentiation of sea urchin embryos is disrupted in response to calcium ionophore. Development, Growth \& Differentiation, 39 (3), 373-379.

Al-Subiai, S.N., Arlt, V.M., Frickers, P.E., Readman, J.W., Stolpe, B., Lead, J.R., Moody, A.J., and Jha, A.N., 2012. Merging nano-genotoxicology with eco-genotoxicology: An integrated approach to determine interactive genotoxic and sub-lethal toxic effects of C60 fullerenes and fluoranthene in marine mussels, Mytilus sp. Mutation Research/Genetic Toxicology and Environmental Mutagenesis, 745 (1), 92-103.

Aruoja, V., Dubourguier, H.-C., Kasemets, K., and Kahru, A., 2009. Toxicity of nanoparticles of $\mathrm{CuO}, \mathrm{ZnO}$ and $\mathrm{TiO} 2$ to microalgae Pseudokirchneriella subcapitata. The Science of the Total Environment, 407 (4), 1461-1468.

Ashburner, M., Ball, C.A., Blake, J.A., Botstein, D., Butler, H., Cherry, J.M., Davis, A.P., Dolinski, K., Dwight, S.S., Eppig, J.T., Harris, M.A., Hill, D.P., Issel-Tarver, L., Kasarskis, A., Lewis, S., Matese, J.C., Richardson, J.E., Ringwald, M., Rubin, G.M., and Sherlock, G., 2000. Gene ontology: tool for the unification of biology. The Gene Ontology Consortium. Nature Genetics, 25 (1), 25-29.

Bachelet-Violette, L., Silva, A.K.A., Maire, M., Michel, A., Brinza, O., Ou, P., Ollivier, V., Nicoletti, A., Wilhelm, C., Letourneur, D., Ménager, C., and Chaubet, F., 2014. Strong and specific interaction of ultra small superparamagnetic iron oxide nanoparticles and human activated platelets mediated by fucoidan coating. RSC Advances, 4 (10), 4864-4871. Baker, T.J., Tyler, C.R., and Galloway, T.S., 2014. Impacts of metal and metal oxide 
nanoparticles on marine organisms. Environmental Pollution, 186, 257-271.

Baltaci, A.K. and Yuce, K., 2018. Zinc Transporter Proteins. Neurochemical Research, 43

(3), 517-530.

Bardou, P., Mariette, J., Escudié, F., Djemiel, C., and Klopp, C., 2014. jvenn: an interactive Venn diagram viewer. BMC bioinformatics, 15, 293.

Blinova, I., Ivask, A., Heinlaan, M., Mortimer, M., and Kahru, A., 2010. Ecotoxicity of nanoparticles of $\mathrm{CuO}$ and $\mathrm{ZnO}$ in natural water. Environmental Pollution, 158 (1), 41-47.

Bondarenko, O., Juganson, K., Ivask, A., Kasemets, K., Mortimer, M., and Kahru, A., 2013. Toxicity of $\mathrm{Ag}, \mathrm{CuO}$ and $\mathrm{ZnO}$ nanoparticles to selected environmentally relevant test organisms and mammalian cells in vitro: a critical review. Archives of Toxicology, 87 (7), $1181-1200$.

Brayner, R., Couté, A., Livage, J., Perrette, C., and Sicard, C., 2011. Micro-algal biosensors. Analytical and Bioanalytical Chemistry, 401 (2), 581-597.

Bundschuh, M., Filser, J., Lüderwald, S., McKee, M.S., Metreveli, G., Schaumann, G.E., Schulz, R., and Wagner, S., 2018. Nanoparticles in the environment: where do we come from, where do we go to? Environmental Sciences Europe, 30 (1).

Canesi, L. and Corsi, I., 2016. Effects of nanomaterials on marine invertebrates. The Science of the Total Environment, 565, 933-940.

Carballeira, C., Ramos-Gómez, J., Martín-Díaz, L., and DelValls, T.A., 2012. Identification of specific malformations of sea urchin larvae for toxicity assessment: application to marine pisciculture effluents. Marine Environmental Research, 77, 12-22.

Châtel, A. and Mouneyrac, C., 2017. Signaling pathways involved in metal-based nanomaterial toxicity towards aquatic organisms. Comparative Biochemistry and Physiology Part C: Toxicology \& Pharmacology, 196, 61-70.

Chen, F., Xiao, Z., Yue, L., Wang, J., Feng, Y., Zhu, X., Wang, Z., and Xing, B., 2019. Algae 
response to engineered nanoparticles: current understanding, mechanisms and implications. Environmental Science: Nano, 6 (4), 1026-1042.

Chiu, M.-H., Khan, Z.A., Garcia, S.G., Le, A.D., Kagiri, A., Ramos, J., Tsai, S.-M., Drobenaire, H.W., Santschi, P.H., Quigg, A., and Chin, W.-C., 2017. Effect of Engineered Nanoparticles on Exopolymeric Substances Release from Marine Phytoplankton. Nanoscale Research Letters, 12 (1), 620.

Coffman, J.A. and Davidson, E.H., 2001. Oral-Aboral Axis Specification in the Sea Urchin Embryo. Developmental Biology, 230 (1), 18-28.

Covian-Nares, J.F., Smith, R.M., and Vogel, S.S., 2008. Two independent forms of endocytosis maintain embryonic cell surface homeostasis during early development. Developmental Biology, 316 (1), 135-148.

Crawford, B.J. and Burke, R.D., 2004. TEM and SEM Methods. In: Methods in Cell Biology. Academic Press, 411-441.

Cuvelier, M.L., Guo, J., Ortiz, A.C., van Baren, M.J., Tariq, M.A., Partensky, F., and Worden, A.Z., 2017. Responses of the picoprasinophyte Micromonas commoda to light and ultraviolet stress. PloS One, 12 (3), e0172135.

Derelle, E., Ferraz, C., Escande, M.-L., Eychenié, S., Cooke, R., Piganeau, G., Desdevises, Y., Bellec, L., Moreau, H., and Grimsley, N., 2008. Life-cycle and genome of OtV5, a large DNA virus of the pelagic marine unicellular green alga Ostreococcus tauri. PloS One, 3 (5), e2250.

Exbrayat, J.-M., Moudilou, E.N., and Lapied, E., 2015. Harmful Effects of Nanoparticles on Animals [online]. Journal of Nanotechnology. Available from: https://www.hindawi.com/journals/jnt/2015/861092/ [Accessed 12 Mar 2020]. Fairbairn, E.A., Keller, A.A., Mädler, L., Zhou, D., Pokhrel, S., and Cherr, G.N., 2011. Metal oxide nanomaterials in seawater: linking physicochemical characteristics with biological 
response in sea urchin development. Journal of Hazardous Materials, 192 (3), 1565-1571. Franklin, N.M., Rogers, N.J., Apte, S.C., Batley, G.E., Gadd, G.E., and Casey, P.S., 2007. Comparative toxicity of nanoparticulate $\mathrm{ZnO}$, bulk $\mathrm{ZnO}$, and $\mathrm{ZnCl} 2$ to a freshwater microalga (Pseudokirchneriella subcapitata): the importance of particle solubility. Environmental Science \& Technology, 41 (24), 8484-8490.

Gambardella, C., Ferrando, S., Gatti, A.M., Cataldi, E., Ramoino, P., Aluigi, M.G., Faimali, M., Diaspro, A., and Falugi, C., 2016. Review: Morphofunctional and biochemical markers of stress in sea urchin life stages exposed to engineered nanoparticles. Environmental Toxicology, 31 (11), 1552-1562.

George, S., Pokhrel, S., Xia, T., Gilbert, B., Ji, Z., Schowalter, M., Rosenauer, A., Damoiseaux, R., Bradley, K.A., Mädler, L., and Nel, A.E., 2010. Use of a rapid cytotoxicity screening approach to engineer a safer zinc oxide nanoparticle through iron doping. $A C S$ nano, 4 (1), 15-29.

Gottschalk, F., Lassen, C., Kjoelholt, J., Christensen, F., and Nowack, B., 2015. Modeling flows and concentrations of nine engineered nanomaterials in the Danish environment. International Journal of Environmental Research and Public Health, 12 (5), 5581-5602. Gottschalk, F., Sun, T., and Nowack, B., 2013. Environmental concentrations of engineered nanomaterials: review of modeling and analytical studies. Environmental Pollution (Barking, Essex: 1987), 181, 287-300.

Guillard, R.R.L. and Hargraves, P.E., 1993. Stichochrysis immobilis is a diatom, not a chrysophyte. Phycologia, 32 (3), 234-236.

Hanssen, K.Ø., Andersen, J.H., Stiberg, T., Engh, R.A., Svenson, J., Genevière, A.-M., and Hansen, E., 2012. Antitumoral and mechanistic studies of ianthelline isolated from the Arctic sponge Stryphnus fortis. Anticancer Research, 32 (10), 4287-4297.

Heinlaan, M., Ivask, A., Blinova, I., Dubourguier, H.-C., and Kahru, A., 2008. Toxicity of 
nanosized and bulk $\mathrm{ZnO}, \mathrm{CuO}$ and $\mathrm{TiO} 2$ to bacteria Vibrio fischeri and crustaceans Daphnia magna and Thamnocephalus platyurus. Chemosphere, 71 (7), 1308-1316.

Hou, J., Wu, Y., Li, X., Wei, B., Li, S., and Wang, X., 2018. Toxic effects of different types of zinc oxide nanoparticles on algae, plants, invertebrates, vertebrates and microorganisms. Chemosphere, 193, 852-860.

Huang, K., Diener, D.R., Mitchell, A., Pazour, G.J., Witman, G.B., and Rosenbaum, J.L., 2007. Function and dynamics of PKD2 in Chlamydomonas reinhardtii flagella. The Journal of Cell Biology, 179 (3), 501-514.

Kadar, E., Simmance, F., Martin, O., Voulvoulis, N., Widdicombe, S., Mitov, S., Lead, J.R., and Readman, J.W., 2010. The influence of engineered Fe2O3 nanoparticles and soluble ( $\mathrm{FeCl} 3)$ iron on the developmental toxicity caused by $\mathrm{CO} 2$-induced seawater acidification. Environmental Pollution, 158 (12), 3490-3497.

Kanehisa, M., Araki, M., Goto, S., Hattori, M., Hirakawa, M., Itoh, M., Katayama, T., Kawashima, S., Okuda, S., Tokimatsu, T., and Yamanishi, Y., 2008. KEGG for linking genomes to life and the environment. Nucleic Acids Research, 36 (Database issue), D480484.

Kanehisa, M., Goto, S., Hattori, M., Aoki-Kinoshita, K.F., Itoh, M., Kawashima, S., Katayama, T., Araki, M., and Hirakawa, M., 2006. From genomics to chemical genomics: new developments in KEGG. Nucleic Acids Research, 34 (Database issue), D354-357. Keller, A.A. and Lazareva, A., 2014. Predicted Releases of Engineered Nanomaterials: From Global to Regional to Local. Environmental Science \& Technology Letters, 1 (1), 65-70. Keller, A.A., Wang, H., Zhou, D., Lenihan, H.S., Cherr, G., Cardinale, B.J., Miller, R., and Ji, Z., 2010. Stability and aggregation of metal oxide nanoparticles in natural aqueous matrices. Environmental Science \& Technology, 44 (6), 1962-1967.

Kim, R.-O., Choi, J.S., Kim, B.-C., and Kim, W.-K., 2017. Comparative Analysis of 
Transcriptional Profile Changes in Larval Zebrafish Exposed to Zinc Oxide Nanoparticles and Zinc Sulfate. Bulletin of Environmental Contamination and Toxicology, 98 (2), 183-189.

Klimova, E.M., Bozhkov, A.I., Bychenko, E.A., Lavinskaya, E.V., Zholobak, N.M., and Korobov, A.M., 2019. Characteristics of the response of the microalga (Dunaliella viridis) to cerium compounds in culture. Biosystems Diversity, 27 (2), 142-147.

Landa, P., Vankova, R., Andrlova, J., Hodek, J., Marsik, P., Storchova, H., White, J.C., and Vanek, T., 2012. Nanoparticle-specific changes in Arabidopsis thaliana gene expression after exposure to $\mathrm{ZnO}, \mathrm{TiO} 2$, and fullerene soot. Journal of Hazardous Materials, 241-242, 55-62. Lead, J.R., Batley, G.E., Alvarez, P.J.J., Croteau, M.-N., Handy, R.D., McLaughlin, M.J., Judy, J.D., and Schirmer, K., 2018. Nanomaterials in the environment: Behavior, fate, bioavailability, and effects-An updated review. Environmental Toxicology and Chemistry, 37 (8), 2029-2063.

Levy, M., Luciani, N., Alloyeau, D., Elgrabli, D., Deveaux, V., Pechoux, C., Chat, S., Wang, G., Vats, N., Gendron, F., Factor, C., Lotersztajn, S., Luciani, A., Wilhelm, C., and Gazeau, F., 2011. Long term in vivo biotransformation of iron oxide nanoparticles. Biomaterials, 32 (16), 3988-3999.

Lewinski, N., Colvin, V., and Drezek, R., 2008. Cytotoxicity of Nanoparticles. Small, 4 (1), 26-49.

Ma, H., Bertsch, P.M., Glenn, T.C., Kabengi, N.J., and Williams, P.L., 2009. Toxicity of manufactured zinc oxide nanoparticles in the nematode Caenorhabditis elegans. Environmental Toxicology and Chemistry, 28 (6), 1324-1330.

Ma, H., Williams, P.L., and Diamond, S.A., 2013. Ecotoxicity of manufactured ZnO nanoparticles - A review. Environmental Pollution, 172, 76-85.

Magro, M., Sinigaglia, G., Nodari, L., Tucek, J., Polakova, K., Marusak, Z., Cardillo, S., Salviulo, G., Russo, U., Stevanato, R., Zboril, R., and Vianello, F., 2012. Charge binding of 
rhodamine derivative to $\mathrm{OH}^{-}$stabilized nanomaghemite: Universal nanocarrier for construction of magnetofluorescent biosensors. Acta Biomaterialia, 8 (6), 2068-2076. Majedi, S.M., Lee, H.K., and Kelly, B.C., 2012. Chemometric Analytical Approach for the Cloud Point Extraction and Inductively Coupled Plasma Mass Spectrometric Determination of Zinc Oxide Nanoparticles in Water Samples. Analytical Chemistry, 84 (15), 6546-6552. Manzo, S., Miglietta, M.L., Rametta, G., Buono, S., and Di Francia, G., 2013. Embryotoxicity and spermiotoxicity of nanosized $\mathrm{ZnO}$ for Mediterranean sea urchin Paracentrotus lividus. Journal of Hazardous Materials, 254-255, 1-9.

Marcus, M., Karni, M., Baranes, K., Levy, I., Alon, N., Margel, S., and Shefi, O., 2016. Iron oxide nanoparticles for neuronal cell applications: uptake study and magnetic manipulations. Journal of Nanobiotechnology, 14.

Marisa, I., Matozzo, V., Munari, M., Binelli, A., Parolini, M., Martucci, A., Franceschinis, E., Brianese, N., and Marin, M.G., 2016. In vivo exposure of the marine clam Ruditapes philippinarum to zinc oxide nanoparticles: responses in gills, digestive gland and haemolymph. Environmental Science and Pollution Research International, 23 (15), 1527515293.

Marrone, V., Piscopo, M., Romano, G., Ianora, A., Palumbo, A., and Costantini, M., 2012. Defensome against toxic diatom aldehydes in the sea urchin Paracentrotus lividus. PloS One, 7 (2), e31750.

Massart, R., 1981. Preparation of aqueous magnetic liquids in alkaline and acidic media. IEEE Transactions on Magnetics, 17 (2), 1247-1248.

Migliaccio, O., Castellano, I., Romano, G., and Palumbo, A., 2014. Stress response to cadmium and manganese in Paracentrotus lividus developing embryos is mediated by nitric oxide. Aquatic Toxicology (Amsterdam, Netherlands), 156, 125-134.

Miller, R.J., Lenihan, H.S., Muller, E.B., Tseng, N., Hanna, S.K., and Keller, A.A., 2010. 
Impacts of Metal Oxide Nanoparticles on Marine Phytoplankton. Environmental Science \& Technology, 44 (19), 7329-7334.

Mitchell, D.R., 2007. The evolution of eukaryotic cilia and flagella as motile and sensory organelles. Advances in Experimental Medicine and Biology, 607, 130-140.

Montané, M.-H. and Kloppstech, K., 2000. The family of light-harvesting-related proteins (LHCs, ELIPs, HLIPs): was the harvesting of light their primary function? Gene, 258 (1), 18.

Montané, M.-H., Petzold, B., and Kloppstech, K., 1999. Formation of early-light-inducibleprotein complexes and status of xanthophyll levels under high light and cold stress in barley (Hordeum vulgare L.). Planta, 208 (4), 519-527.

von Moos, N. and Slaveykova, V.I., 2014. Oxidative stress induced by inorganic nanoparticles in bacteria and aquatic microalgae--state of the art and knowledge gaps. Nanotoxicology, 8 (6), 605-630.

Morelli, E., Gabellieri, E., Bonomini, A., Tognotti, D., Grassi, G., and Corsi, I., 2018. TiO2 nanoparticles in seawater: Aggregation and interactions with the green alga Dunaliella tertiolecta. Ecotoxicology and Environmental Safety, 148, 184-193.

Mukherjee, K. and Acharya, K., 2018. Toxicological Effect of Metal Oxide Nanoparticles on Soil and Aquatic Habitats. Archives of Environmental Contamination and Toxicology, 75 (2), $175-186$.

Oliviero, M., Schiavo, S., Rametta, G., Miglietta, M.L., and Manzo, S., 2017. Different sizes of $\mathrm{ZnO}$ diversely affected the cytogenesis of the sea urchin Paracentrotus lividus. The Science of the Total Environment, 607-608, 176-183.

Park, H.-G. and Yeo, M.-K., 2015. Comparison of gene expression patterns from zebrafish embryos between pure silver nanomaterial and mixed silver nanomaterial containing cells of Hydra magnipapillata. Molecular \& Cellular Toxicology, 11 (3), 307-314. 
Piticharoenphun, S., Šiller, L., Lemloh, M.-L., Salome, M., Cotte, M., Kaulich, B., Gianoncelli, A., Mendis, B.G., Bangert, U., Poolton, N.R.J., Horrocks, B.R., Brümmer, F., and Medaković, D., 2012. Agglomeration of Silver Nanoparticles in Sea Urchin. International Journal of Environmental Pollution and Remediation.

Polak, N., Read, D.S., Jurkschat, K., Matzke, M., Kelly, F.J., Spurgeon, D.J., and Stürzenbaum, S.R., 2014. Metalloproteins and phytochelatin synthase may confer protection against zinc oxide nanoparticle induced toxicity in Caenorhabditis elegans. Comparative Biochemistry and Physiology Part C: Toxicology \& Pharmacology, 160, 75-85.

Qian, H., Zhu, K., Lu, H., Lavoie, M., Chen, S., Zhou, Z., Deng, Z., Chen, J., and Fu, Z., 2016. Contrasting silver nanoparticle toxicity and detoxification strategies in Microcystis aeruginosa and Chlorella vulgaris: New insights from proteomic and physiological analyses. Science of The Total Environment, 572, 1213-1221.

Quigg, A., Chin, W.-C., Chen, C.-S., Zhang, S., Jiang, Y., Miao, A.-J., Schwehr, K.A., Xu, C., and Santschi, P.H., 2013. Direct and Indirect Toxic Effects of Engineered Nanoparticles on Algae: Role of Natural Organic Matter. ACS Sustainable Chemistry \& Engineering, 1 (7), $686-702$.

Ragusa, M.A., Costa, S., Cuttitta, A., Gianguzza, F., and Nicosia, A., 2017. Coexposure to sulfamethoxazole and cadmium impairs development and attenuates transcriptional response in sea urchin embryo. Chemosphere, 180, 275-284.

Robinson, M.D., McCarthy, D.J., and Smyth, G.K., 2010. edgeR: a Bioconductor package for differential expression analysis of digital gene expression data. Bioinformatics, 26 (1), 139140.

Roccheri, M.C., Agnello, M., Bonaventura, R., and Matranga, V., 2004. Cadmium induces the expression of specific stress proteins in sea urchin embryos. Biochemical and Biophysical Research Communications, 321 (1), 80-87. 
Rocha, T.L., Gomes, T., Sousa, V.S., Mestre, N.C., and Bebianno, M.J., 2015.

Ecotoxicological impact of engineered nanomaterials in bivalve molluscs: An overview. Marine Environmental Research, 111, 74-88.

Roger, J., Pons, J.N., Massart, R., Halbreich, A., and Bacri, J.C., 1999. Some biomedical applications of ferrofluids. The European Physical Journal Applied Physics, 5 (3), 321-325. Russo, R., Bonaventura, R., and Matranga, V., 2014. Time- and dose-dependent gene expression in sea urchin embryos exposed to UVB. Marine Environmental Research, 93, 8592.

Satori, C.P., Kostal, V., and Arriaga, E.A., 2011. Individual organelle pH determinations of magnetically-enriched endocytic organelles via laser-induced fluorescence detection. Analytical chemistry, 83 (19), 7331-7339.

Scheibe, R., 2004. Malate valves to balance cellular energy supply. Physiologia Plantarum, $120(1), 21-26$.

Silva, B.F. da, Pérez, S., Gardinalli, P., Singhal, R.K., Mozeto, A.A., and Barceló, D., 2011. Analytical chemistry of metallic nanoparticles in natural environments. TrAC Trends in Analytical Chemistry, 30 (3), 528-540.

Singhal, R.K., Preetha, J., Karpe, R., Tirumalesh, K., Kumar, S.C., and Hegde, A.G., 2006. The use of ultra filtration in trace metal speciation studies in sea water. Environment International, 32 (2), 224-228.

Su, G., Zhang, X., Giesy, J.P., Musarrat, J., Saquib, Q., Alkhedhairy, A.A., and Yu, H., 2015. Comparison on the molecular response profiles between nano zinc oxide $(\mathrm{ZnO})$ particles and free zinc ion using a genome-wide toxicogenomics approach. Environmental Science and Pollution Research, 22 (22), 17434-17442.

Sun, Z. and Ettensohn, C.A., 2017. TGF- $\beta$ sensu stricto signaling regulates skeletal morphogenesis in the sea urchin embryo. Developmental Biology, 421 (2), 149-160. 
Torres-Duarte, C., Adeleye, A.S., Pokhrel, S., Mädler, L., Keller, A.A., and Cherr, G.N., 2016. Developmental effects of two different copper oxide nanomaterials in sea urchin (Lytechinus pictus) embryos. Nanotoxicology, 10 (6), 671-679.

Torres-Duarte, C., Ramos-Torres, K.M., Rahimoff, R., and Cherr, G.N., 2017. Stage specific effects of soluble copper and copper oxide nanoparticles during sea urchin embryo development and their relation to intracellular copper uptake. Aquatic Toxicology (Amsterdam, Netherlands), 189, 134-141.

Trask, B.J., van den Engh, G.J., and Elgershuizen, J.H., 1982. Analysis of phytoplankton by flow cytometry. Cytometry, 2 (4), 258-264.

Tsiokas, L., 2009. Function and regulation of TRPP2 at the plasma membrane. American Journal of Physiology. Renal Physiology, 297 (1), F1-9.

Tualla, I.P.B. and Bitacura, J.G., 2016. Effects of Cadmium and Zinc on the Gamete Viability, Fertilization, and Embryonic Development of Tripneustes gratilla (Linnaeus). Scientifica, 2016, 8175213.

Valdiglesias, V., Fernández-Bertólez, N., Kiliç, G., Costa, C., Costa, S., Fraga, S., Bessa, M.J., Pásaro, E., Teixeira, J.P., and Laffon, B., 2016. Are iron oxide nanoparticles safe? Current knowledge and future perspectives. Journal of Trace Elements in Medicine and Biology, 38, 53-63.

Wong, S.W.Y., Leung, P.T.Y., Djurišić, A.B., and Leung, K.M.Y., 2010. Toxicities of nano zinc oxide to five marine organisms: influences of aggregate size and ion solubility. Analytical and Bioanalytical Chemistry, 396 (2), 609-618.

Worden, A.Z., Lee, J.-H., Mock, T., Rouzé, P., Simmons, M.P., Aerts, A.L., Allen, A.E., Cuvelier, M.L., Derelle, E., Everett, M.V., Foulon, E., Grimwood, J., Gundlach, H., Henrissat, B., Napoli, C., McDonald, S.M., Parker, M.S., Rombauts, S., Salamov, A., Von Dassow, P., Badger, J.H., Coutinho, P.M., Demir, E., Dubchak, I., Gentemann, C., Eikrem, 
W., Gready, J.E., John, U., Lanier, W., Lindquist, E.A., Lucas, S., Mayer, K.F.X., Moreau, H., Not, F., Otillar, R., Panaud, O., Pangilinan, J., Paulsen, I., Piegu, B., Poliakov, A., Robbens, S., Schmutz, J., Toulza, E., Wyss, T., Zelensky, A., Zhou, K., Armbrust, E.V., Bhattacharya, D., Goodenough, U.W., Van de Peer, Y., and Grigoriev, I.V., 2009. Green evolution and dynamic adaptations revealed by genomes of the marine picoeukaryotes Micromonas. Science (New York, N.Y.), 324 (5924), 268-272.

Wu, B., Torres-Duarte, C., Cole, B.J., and Cherr, G.N., 2015. Copper oxide and zinc oxide nanomaterials act as inhibitors of multidrug resistance transport in sea urchin embryos: their role as chemosensitizers. Environmental Science \& Technology, 49 (9), 5760-5770.

Xia, T., Kovochich, M., Liong, M., Mädler, L., Gilbert, B., Shi, H., Yeh, J.I., Zink, J.I., and Nel, A.E., 2008. Comparison of the Mechanism of Toxicity of Zinc Oxide and Cerium Oxide Nanoparticles Based on Dissolution and Oxidative Stress Properties. ACS Nano, 2 (10), $2121-2134$.

Yung, M.M.N., Wong, S.W.Y., Kwok, K.W.H., Liu, F.Z., Leung, Y.H., Chan, W.T., Li, X.Y., Djurišić, A.B., and Leung, K.M.Y., 2015. Salinity-dependent toxicities of zinc oxide nanoparticles to the marine diatom Thalassiosira pseudonana. Aquatic Toxicology, 165, 3140.

Zhao, X., Wang, S., Wu, Y., You, H., and Lv, L., 2013. Acute ZnO nanoparticles exposure induces developmental toxicity, oxidative stress and DNA damage in embryo-larval zebrafish. Aquatic Toxicology, 136-137, 49-59.

Zhou, C., Carotenuto, Y., Vitiello, V., Wu, C., Zhang, J., and Buttino, I., 2018. De novo transcriptome assembly and differential gene expression analysis of the calanoid copepod Acartia tonsa exposed to nickel nanoparticles. Chemosphere, 209, 163-172. 


\section{Figure captions:}

Figure 1. TEM analysis of $\gamma-\mathrm{Fe}_{2} \mathrm{O}_{3}$ (A) and $\mathrm{ZnO}$ (B) ENPs dispersed in NFSW. Evolution of the hydrodynamic diameter $(\mathrm{C})$ of $\mathrm{Fe}_{2} \mathrm{O}_{3}$ ENPs dispersed in NFSW, $[\mathrm{Fe}]=5.10^{-3} \mathrm{~mol} / \mathrm{L}$ at $20^{\circ} \mathrm{C}$. Dotted lines represent the sedimentation threshold. TEM analysis of $\gamma-\mathrm{Fe}_{2} \mathrm{O}_{3}$ ENP dispersed in L1 algal culture medium along the time (D-F). Scale bar $100 \mathrm{~nm}$.

Figure 2. Developmental abnormalities of $P$. lividus embryos observed $48 \mathrm{~h}$ post fertilization. Embryos were maintained in NFSW (A), the control condition, or exposed to $\mathrm{Fe}_{2} \mathrm{O}_{3}$ ENPs (B) or $\mathrm{FeCl}_{3}(\mathrm{C})$ at $510^{-5} \mathrm{~mol} / \mathrm{L}$ and $\mathrm{ZnO}$ ENPs (D) or $\mathrm{ZnSO}_{4}(\mathrm{E})$ at $110^{-5} \mathrm{~mol} / \mathrm{L}$. Dose response to zinc derivative exposure $(\mathrm{F})$. These results are representative of three independent experiments. Scale bar $100 \mu \mathrm{m}$.

Figure 3. Internalization of $\mathrm{Fe}_{2} \mathrm{O}_{3}$ ENPs into sea urchin embryos observed by TEM 24h p.f.. Embryos were incubated with $\mathrm{Fe}_{2} \mathrm{O}_{3}$ ENPs at $110^{-4} \mathrm{~mol} / \mathrm{L}$. ENPs are accumulated in vesicles in the cytoplasm of embryonic cells. Cells were observed at low (A) or high magnification $(\mathrm{B}, \mathrm{C})$. A: Blastocoel $(\mathrm{Bl})$ and ectodermal cells $(\mathrm{Ec})$ of the embryo are indicated. B: a white arrow indicates an internal vesicle containing ENPs. C: a cytoplasmic vesicle (V) containing ENPs is indicated close to the outer cell membrane. D: Identification of $\mathrm{Fe}_{2} \mathrm{O}_{3}$ ENPs in internal vesicle was confirmed by TEM with Elemental Analysis. The red arrow in the top spectrum indicate the iron peak. The bottom spectrum correspond to the control zone.

Figure 4. Venn diagrams showing common and specific responses of $P$. lividus embryos exposed to metal ENPs or corresponding ions $\left(5.010^{-5} \mathrm{~mol} / \mathrm{L}[\mathrm{Fe}], 2.810^{-3} \mathrm{~g} / \mathrm{L}\right.$, for $\mathrm{Fe}_{2} \mathrm{O}_{3} \mathrm{ENPs}$ and $10^{-5} \mathrm{~mol} / \mathrm{L}$ [Zn], $6.510^{-4} \mathrm{~g} / \mathrm{L}$, for ZnO ENPs). Up-regulated genes (A) ; down-regulated 
genes (B). The "size of each list" correspond to the number of significantly up- or downregulated genes $($ FDR threshold $=1 \%)$ in response to each treatment.

Figure 5. Time course of $M$. commoda culture growth in response to increasing concentrations of $\mathrm{Fe}_{2} \mathrm{O}_{3}$ (A) or $\mathrm{ZnO}$ ENPs (B). Cells were counted by flow cytometry. IC50 assay for the analysis of half-maximal inhibitory concentration of $\mathrm{Fe}_{2} \mathrm{O}_{3}$ (C) or $\mathrm{ZnO}$ ENPs (D) in $M$. commoda cell culture $48 \mathrm{~h}$ post treatment. Algae were incubated without (control) or with ENPs using $[\mathrm{Fe}]$ or $[\mathrm{Zn}]$ concentration from $10^{-7}$ to $10^{-4} \mathrm{~mol} / \mathrm{L}$. Data were analyzed with GraphpadPrism7. These results are representative of three independent experiments.

Figure 6. TEM images of microalgae exposed to $\mathrm{Fe}_{2} \mathrm{O}_{3}$ ENPs $\left(510^{-5} \mathrm{~mol} / \mathrm{L}\right)$. ENPs appeared in contact with cell surface membranes. C: Chloroplaste, F: Flagellum, M: Mitochondria, N: Nucleus, S: Starch granule. In Fig D, E and F, cells were dividing. Scale bar $100 \mathrm{~nm}$.

Figure 7. Venn diagrams showing common and specific responses of $M$. commoda exposed to metal ENPs or corresponding ions $\left(310^{-5} \mathrm{~mol} / \mathrm{L}[\mathrm{Fe}], 1.710^{-3} \mathrm{~g} / \mathrm{L}\right.$, for $\mathrm{Fe}_{2} \mathrm{O}_{3}$ ENPs and $10^{-5}$ $\mathrm{mol} / \mathrm{L}$ [Zn], $6.510^{-4} \mathrm{~g} / \mathrm{L}$, for ZnO ENPs). Up-regulated genes (A); down-regulated genes (B). The "size of each list" correspond to the number of significantly up- or down-regulated genes $($ FDR threshold $=1 \%)$ in response to each treatment. 

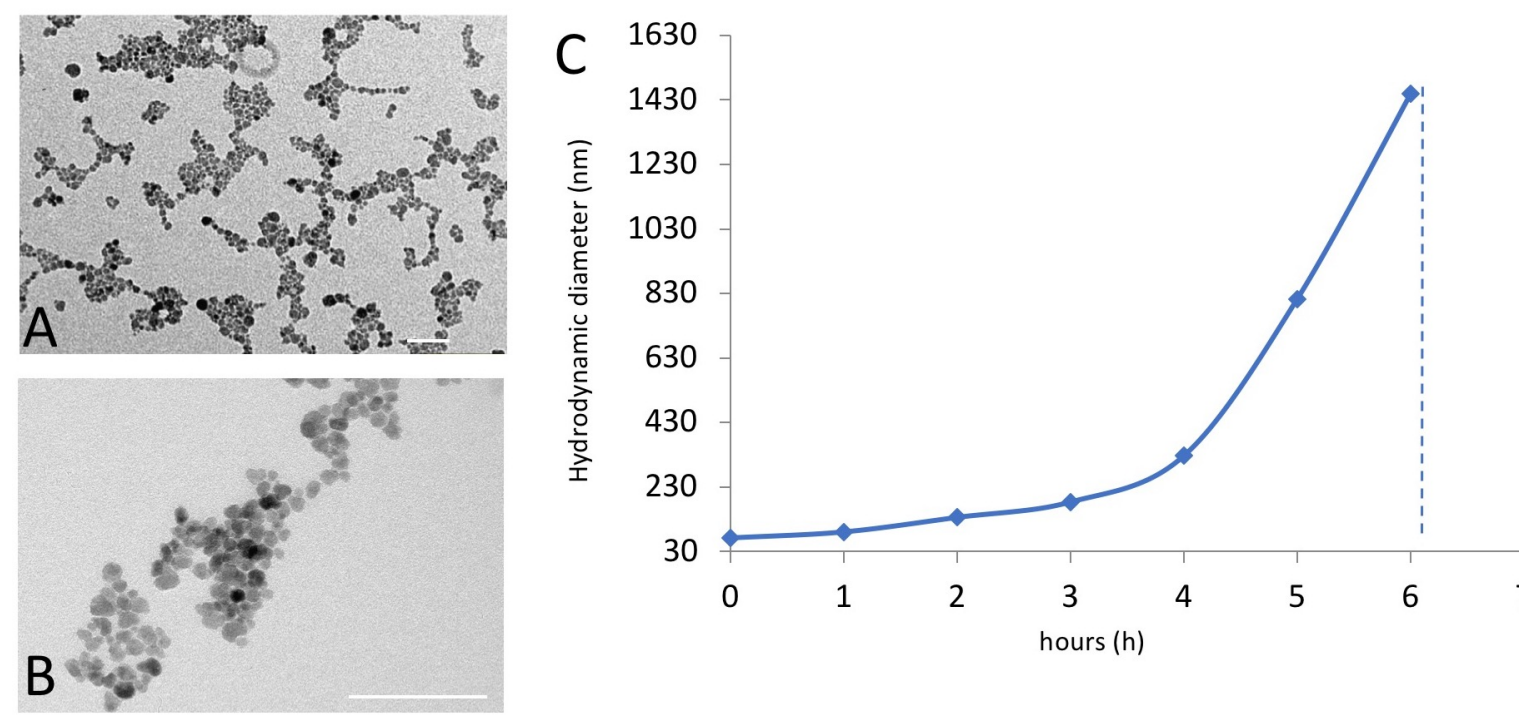

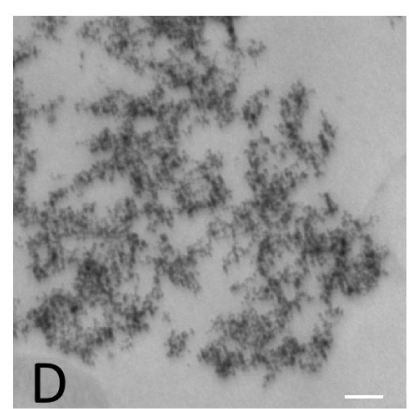

$8 h$

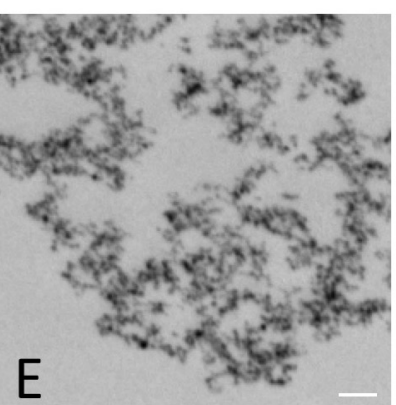

$24 \mathrm{~h}$

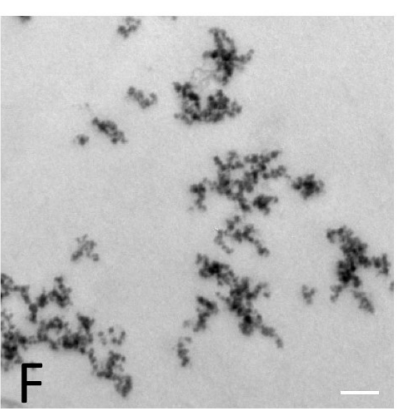

$48 \mathrm{~h}$

Figure 1 

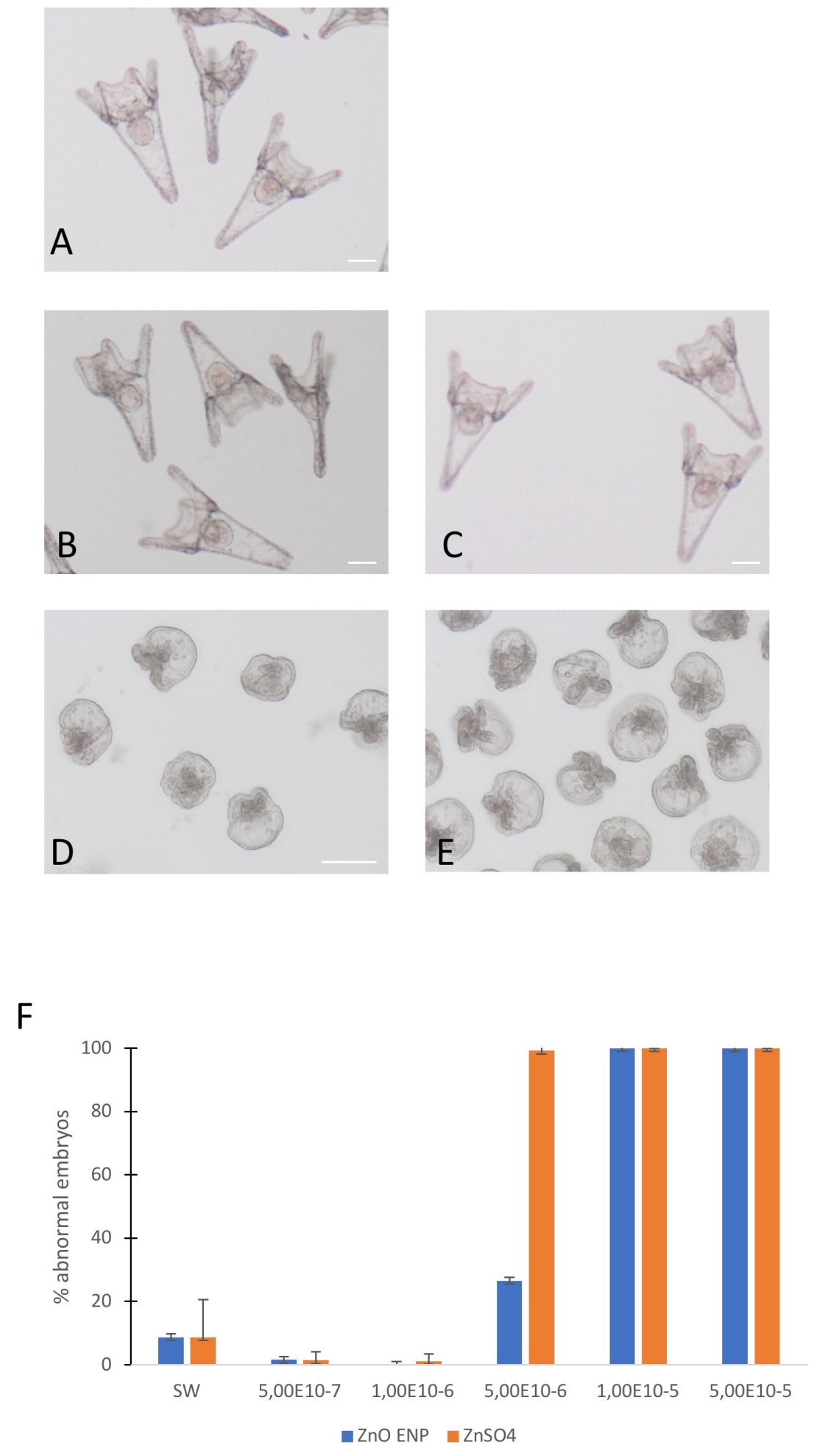

Figure 2 

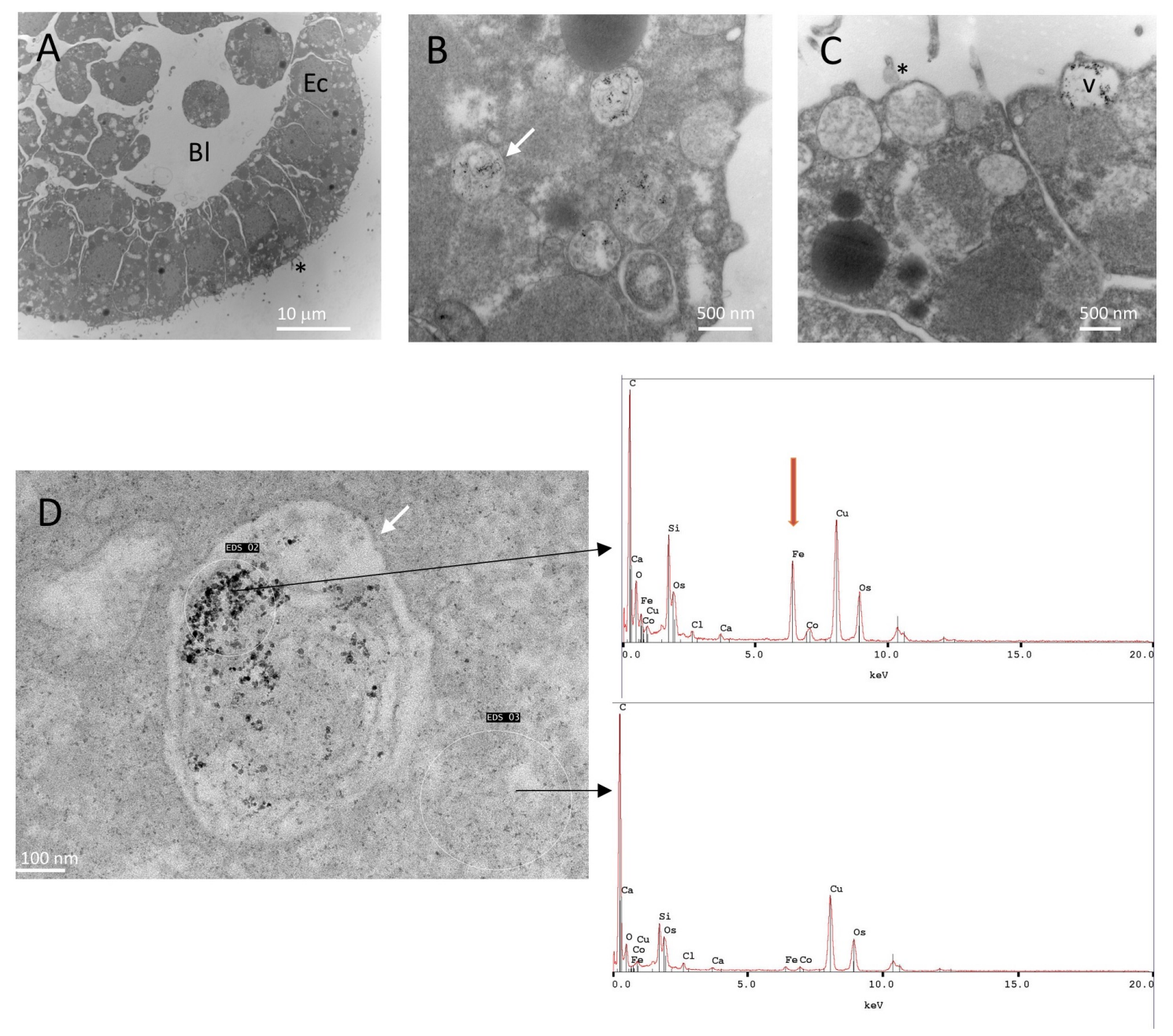

Figure 3 

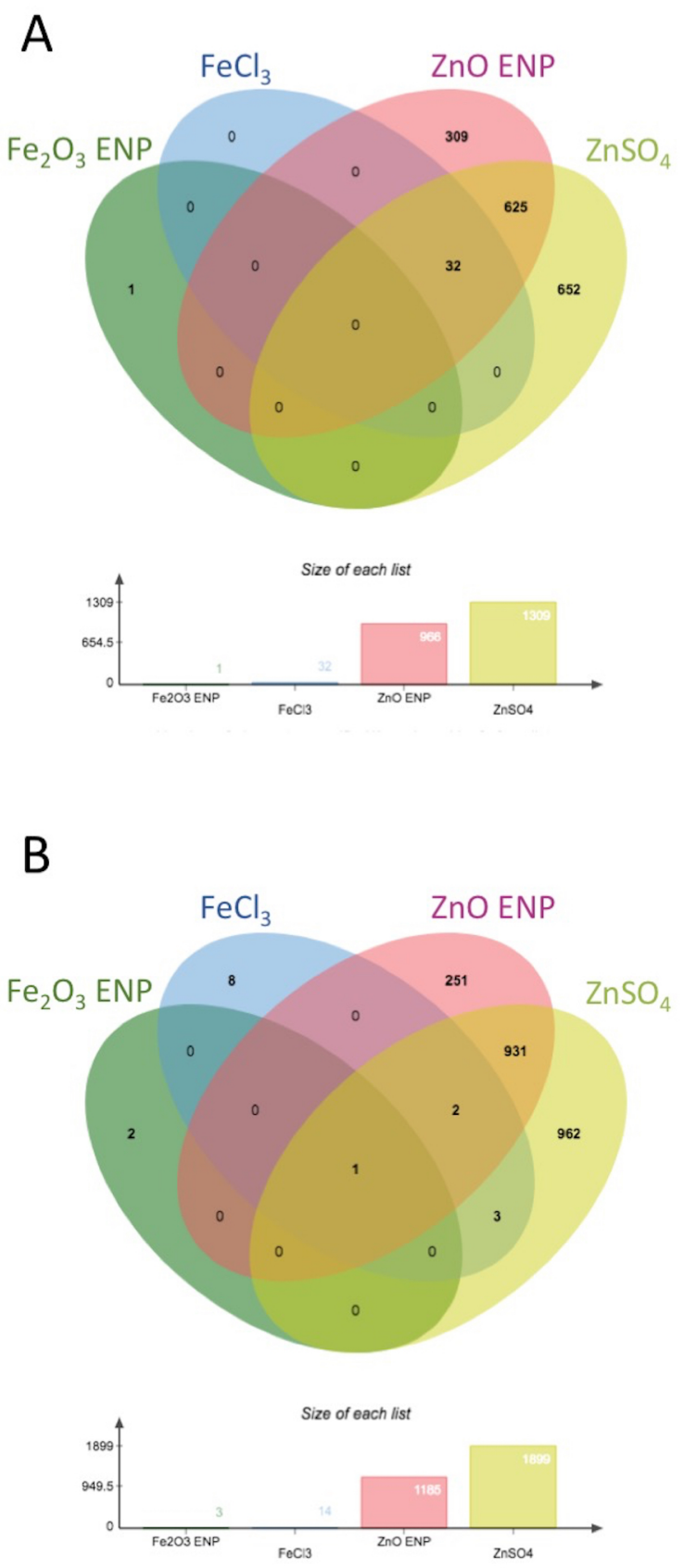

Figure 4 


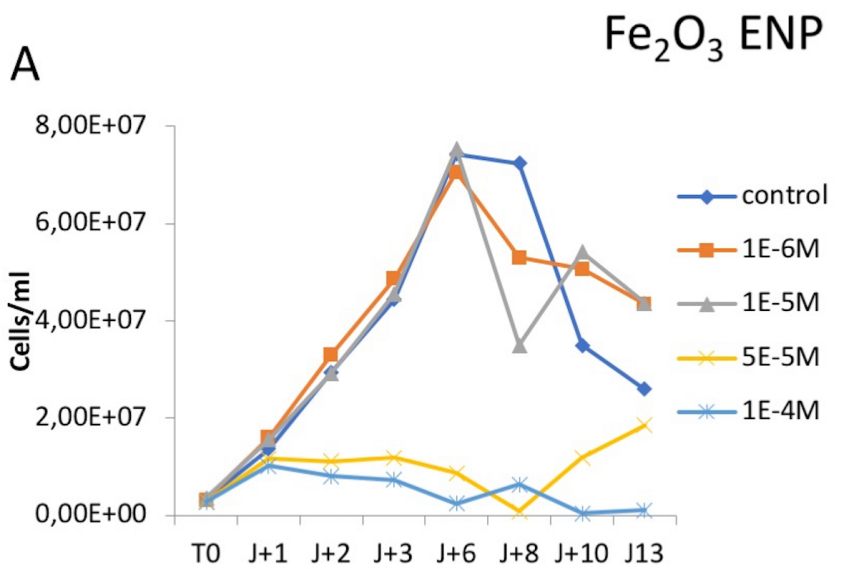

B

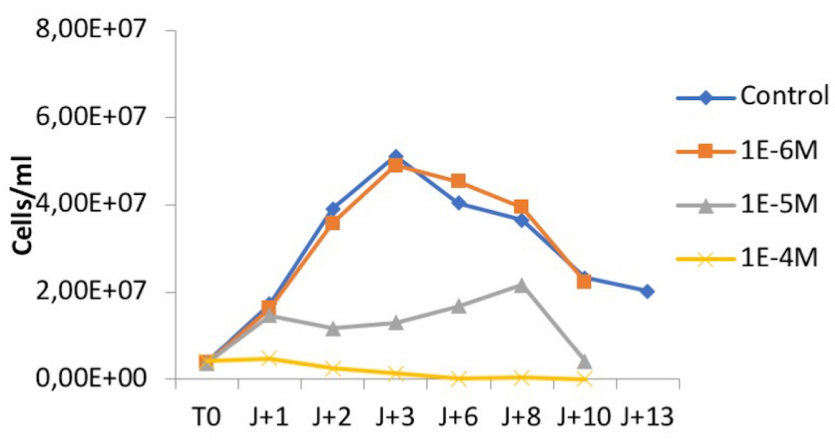

C

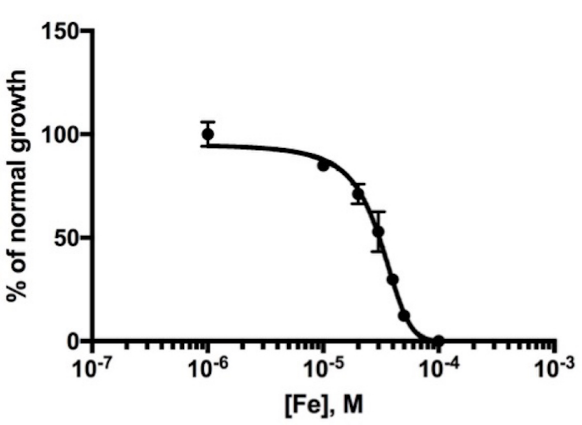

D

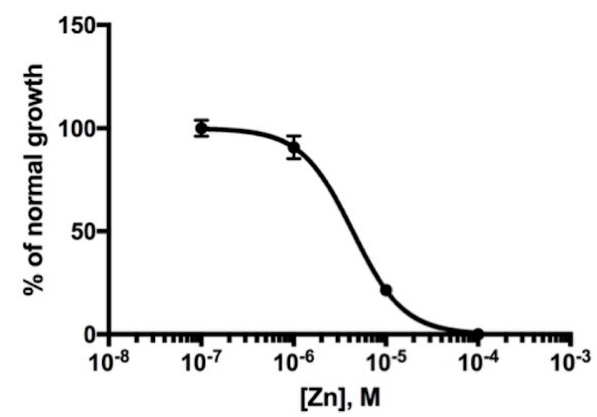

Figure 5 
M. commoda
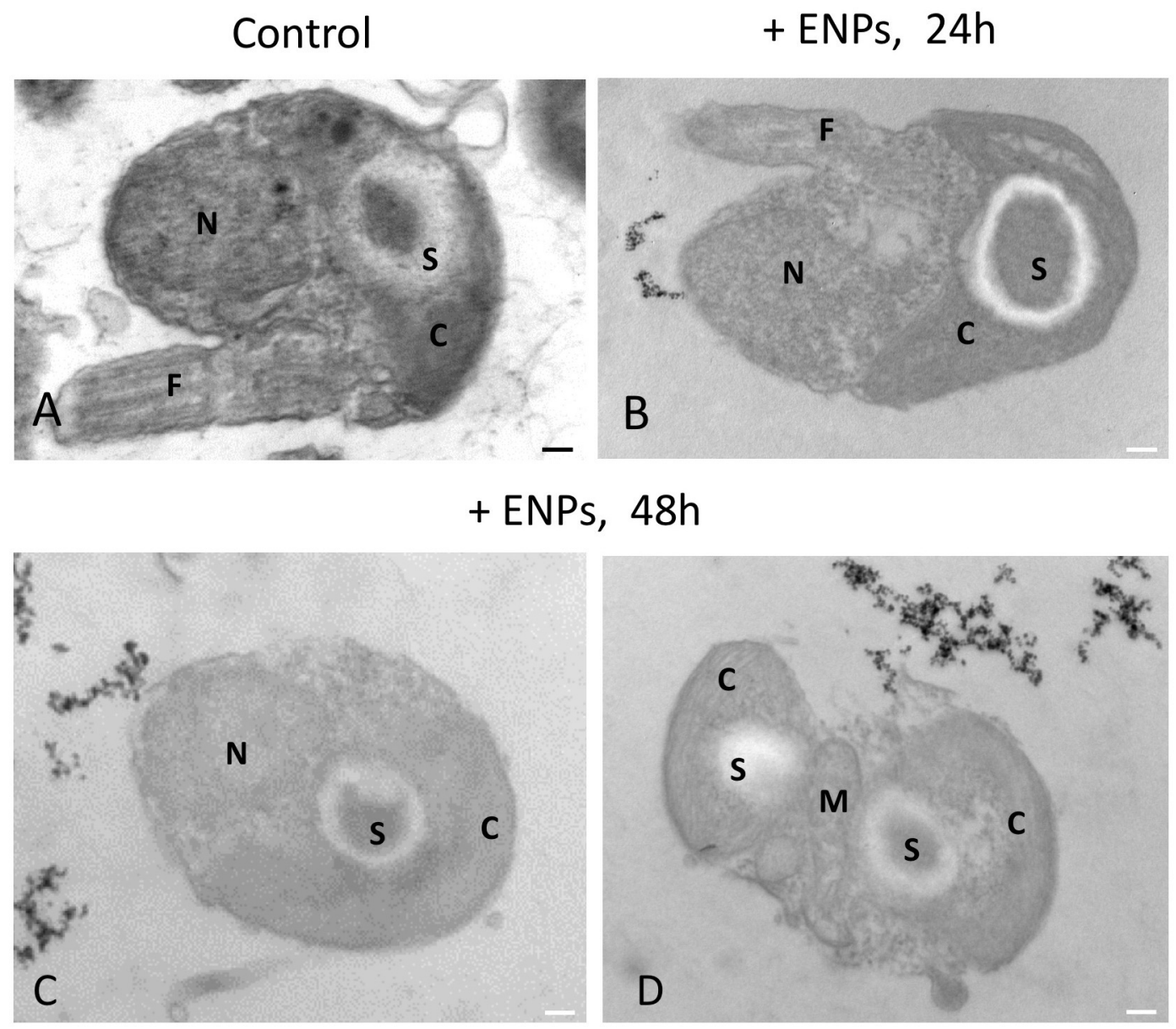

O. tauri
Control
+ ENPs, 24h,
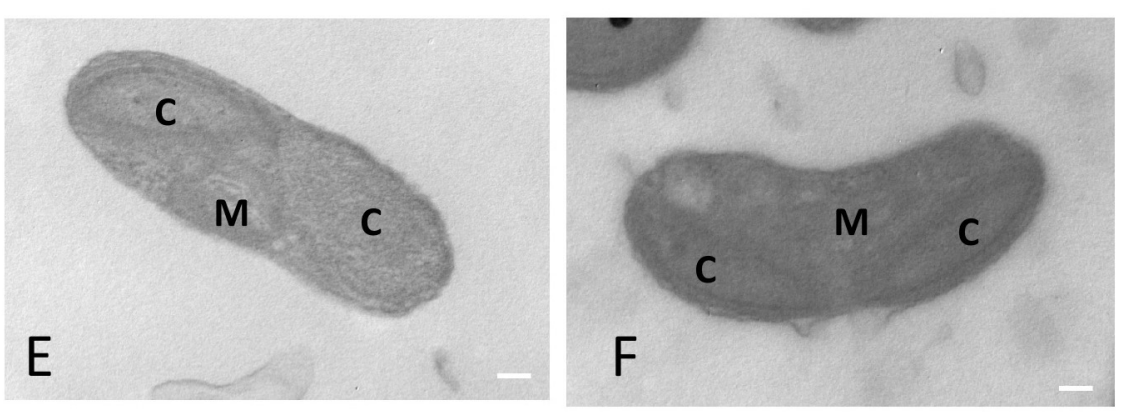

Figure 6 

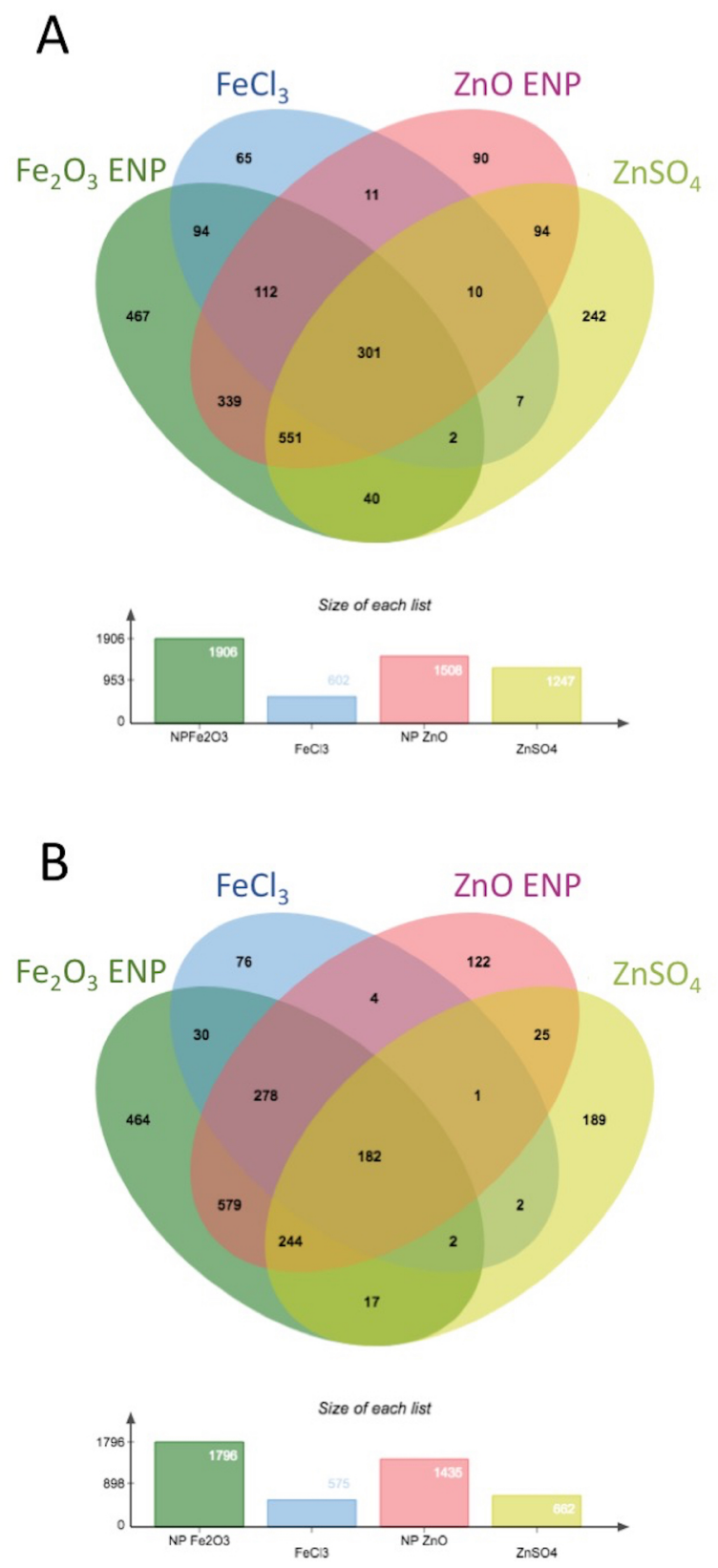

Figure 7 